\title{
Light Quantity and Photosystem Function Mediate Host Susceptibility to Turnip mosaic virus Via a Salicylic Acid-Independent Mechanism
}

\author{
A. Manfre, ${ }^{1}$ M. Glenn, ${ }^{1}$ A. Nuñez, ${ }^{2}$ R. A. Moreau, ${ }^{2}$ and C. Dardick ${ }^{1}$ \\ ${ }^{1}$ United States Department of Agriculture (USDA) Appalachian Fruit Research Station, Kearneysville, WV, U.S.A.; ${ }^{2}$ USDA \\ Eastern Regional Research Center, Wyndmoor, PA, U.S.A.
}

Submitted 26 August 2010. Accepted 10 November 2010.

Evidence going as far back as the early part of the 20th century suggests that both light and chloroplast function may play key roles in host susceptibility to viruses. Despite the long history of such work, confirmation of these phenomena and a determination of the underlying mechanisms remain elusive. Here, we revisited these questions using modern imaging technologies to study the susceptibility of Nicotiana benthamiana to Turnip mosaic virus (TuMV). We found that both light deficiency and photosystem impairment increased the susceptibility of $N$. benthamiana to TuMV infection. Time-lapse photography studies indicated that, under these conditions, rub-inoculated plants exhibited greater numbers of infection foci and more rapid foci development. The rate of systemic movement was also accelerated though cell-to-cell movement appeared unchanged. Inhibition of salicylic acid (SA)-mediated defense responses is not likely responsible for changes in susceptibility because $\mathrm{SA}$ and pathogen response-1 gene induction were not affected by light deficiency or chloroplast impairment and treatment of plants with SA had no measureable impact on TuMV infection. Taken together, these data suggest that both light and optimal chloroplast function influence virus infection either by limiting the cellular resources needed by TuMV to establish replication complexes or the host's ability to activate $\mathrm{SA}$-independent defenses.

As early as the 1940s, published reports began to emerge detailing the impact of light on plant susceptibility to virus infection (Bawden and Roberts 1947, 1948; Cheo 1971; Helms 1965; Helms and McIntyre 1967; Matthews 1953a and b; Wiltshire 1956; Yarwood 1956). These studies used variations in light intensity, photoperiod, and inoculation time of day to investigate changes in host susceptibility to different viruses. Susceptibility was measured via number of lesions formed in incompatible hosts or spectrographic measurements of virus concentration in extracted tissues. In most cases, plants infected in low light or prior to a dark period developed more viral lesions than those placed under high light or inoculated during a light period. Although these reports support a direct relation-

Corresponding author: C. Dardick; E-mail: chris.dardick@ars.usda.gov

* The $\boldsymbol{e}$-Xtra logo stands for "electronic extra" and indicates that three supplementary videos and one supplementary table are published online.

This article is in the public domain and not copyrightable. It may be freely reprinted with customary crediting of the source. The American Phytopathological Society, 2011. ship between light and host susceptibility, they were not definitive, in part because the assays used were indirect and performed primarily in incompatible hosts.

In addition to light, the chloroplast itself has also long been implicated as a common target of plant viruses. In the 1960s, the first electron micrographs showed direct interactions of virus particles with the chloroplast (Esau and Cronshaw 1967). Granett and Shalla (1970) estimated that $1 \%$ of chloroplasts in leaves inoculated with Tobacco mosaic virus (TMV) and $12 \%$ of chloroplasts in systemically infected leaves contained virus-like particles. Since that time, a number of reports have documented direct interactions between virus particles or proteins and chloroplast proteins (Reinero and Beachy 1986; Shalla et al. 1975; Torrance et al. 2006; Xiang et al. 2006). More recently, a number of host-pathogen interaction studies have uncovered evidence that the chloroplast and chloroplast genes are key targets of pathogens during host invasion (Caplan et al. 2008; Curto et al. 2006; Dardick 2007; Jimenez et al. 2006; Jin et al. 2007; Jones et al. 2006; Pineda et al. 2009; Shi et al. 2007; Zhou et al. 2006). These reports suggest that the chloroplast plays an important cellular role during virus invasion and may be targeted for an as-yet-unknown function. Two proposed roles for the targeting of chloroplasts by viruses are its use as a location for virus replication or its role in host defense (Dardick 2007; Griebel and Zeier 2008; Hodgson et al. 1989; Martin et al. 1995; Rodriguez-Cerezo et al. 1997; Wei et al. 2009).

It has been well documented that many positive-strand RNA viruses replicate while in association with host organelle membranes (Ahlquist 2006; Salonen et al. 2005). For example, Turnip yellow mosaic virus and Turnip mosaic virus (TuMV) protein complexes associate with chloroplast membrane invaginations during virus replication (Prod'homme et al. 2003; Wei et al. 2009). These replication complexes (RC) are thought to provide a protected area where the virus can replicate and avoid host defense mechanisms, including RNA silencing (Barajas et al. 2009; Kopek et al. 2007). Though there are many examples of organelles associated with viral RC, very little is known about how they affect the cell or the organelle itself; however, their presence is associated with cytopathic effects, including membrane invagination, vesicle budding, and organelle rupture (Restrepo-Hartwig and Carrington 1994; Ritzenthaler et al. 2002; Turner et al. 2003; Wei et al. 2009).

Plants have evolved elaborate defense strategies to combat the invasion of a wide range of pathogens, including viruses, bacteria, fungi, and insects. They have a fast-acting and multitiered defense system that includes the activation of the salicylic acid (SA), jasmonic acid (JA), or ethylene (ET) signaling pathways (Glazebrook 2001; Gundlach et al. 1992; Métraux et 
al. 1990; Thomma et al. 2001); induction of pathogen response (PR) genes (Alexander et al. 1993; Lebel et al. 1998; Ward et al. 1991); production of reactive oxygen species (ROS) (Baker and Orlandi 1995; Doke 1983; Elstner 1991; Torres et al.

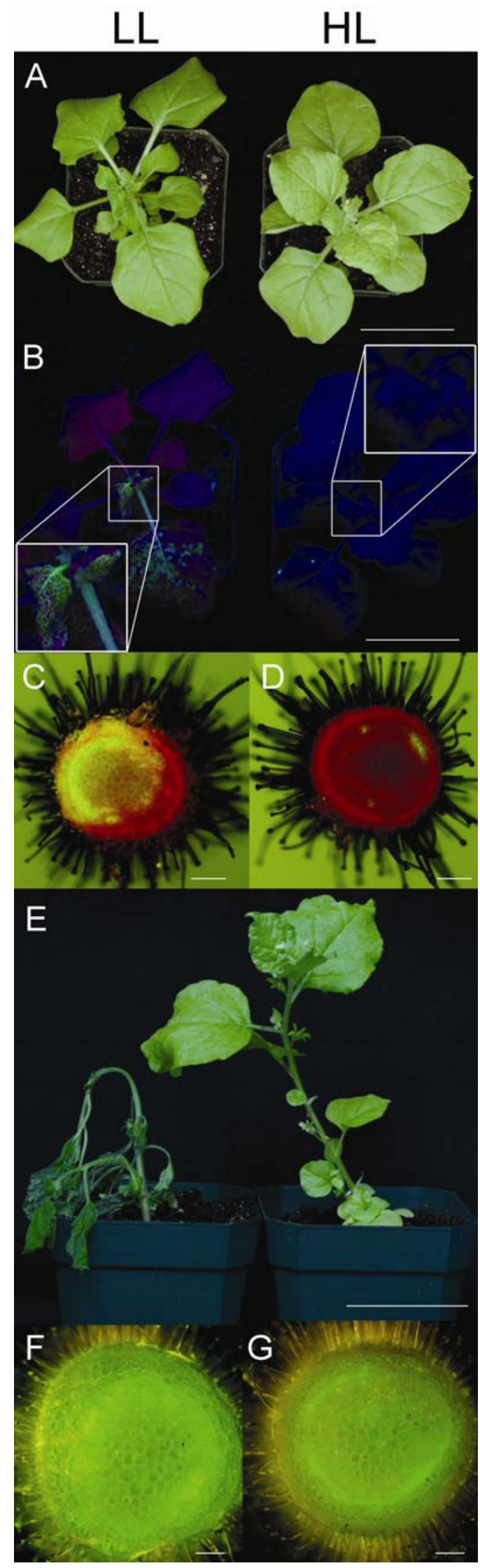

2006); rapid local cell death at the site of infection, called the hypersensitive response (HR) (Dangl et al. 1996; Greenberg, et al. 1994; Slusarenko et al. 1991) deposition of callose (Kim et al. 2005); cell wall strengthening (Bowles 1990; Davis et al. 1997); and RNA silencing (Baulcombe 2004; Meister and Tuschl 2004).

There is evidence that at least some of these defense pathways are dependent upon both light and chloroplast functions. Griebel and Zeier (2008) showed that systemic acquired resistance (SAR) is light dependent and requires the PHYA and PHYB light receptors. Zeier and associates (2004) demonstrated that HR is also light dependent. Jelenska and associates (2007) showed that the Pseudomonas syringae effector protein Hopl1 localized to chloroplasts and suppressed both SA accumulation and SA signaling. Taken together, these examples indicate that both light and chloroplast function are important for proper defense signaling but whether they are limiting to viral infection via defense pathways remains unclear.

We previously showed that virus infection results in the repression of large numbers of nuclear-encoded chloroplast genes and hypothesized that such repression increases host susceptibility (Dardick 2007). To test this hypothesis, we examined whether Nicotiana benthamiana plants would become more susceptible to TuMV under conditions of light deficiency or chloroplast impairment, two conditions known to repress the expression of nuclear-encoded chloroplast genes (Biehl et al. 2005). We further sought to identify the mechanism or mechanisms by which susceptibility was altered. The results of these experiments suggest that both light and photosystem function influence host susceptibility to TuMV in a similar manner.

\section{RESULTS}

Host susceptibility to TuMV is affected by light quantity.

We first set out to determine whether different light intensities would alter the number of TuMV green fluorescent protein (GFP) foci that developed in inoculated $N$. benthamiana leaves (Lellis et al. 2002). Leaves were rub-inoculated with TuMVGFP and then placed in growth chambers under two different light levels: high light (HL) $\left(300 \mu \mathrm{mol} / \mathrm{m}^{-2} \mathrm{~s}^{-1}\right)$ and low light (LL) $\left(20 \mu \mathrm{mol} / \mathrm{m}^{-2} \mathrm{~s}^{-1}\right)$. We monitored leaf temperature under both conditions to eliminate the possibility that changes in TuMV-GFP foci number could be caused by differences in leaf surface temperature instead of the light conditions. Four days after virus challenge, the number of foci per leaf was counted. Plants challenged with TuMV-GFP and grown under LL conditions had three times as many foci $(97.8 \pm 36.4)$ as those grown under HL conditions (29.4 \pm 17.8). An unpaired $t$ test indicated that the difference in foci number was significant to a $P$ value $<0.001$.

By 5 days postinoculation (dpi), GFP was detected in the upper (systemic) leaves of plants grown under LL but not those grown under HL, indicating that TuMV-GFP had moved into systemic tissues more rapidly in LL than in plants grown under

Fig. 1. Changes in severity of Nicotiana benthamiana susceptibility to Turnip mosaic virus-green fluorescent protein (TuMV-GFP) challenge in plants grown under varying light conditions. Plants were placed under low light (LL) $\left(20 \mu \mathrm{mol} / \mathrm{m}^{-2} \mathrm{~s}^{-1}\right)$ or high light (HL) $\left(300 \mu \mathrm{mol} / \mathrm{m}^{-2} \mathrm{~s}^{-1}\right)$ for $24 \mathrm{~h}$ before being mechanically inoculated with TuMV-GFP. A, White light photograph of plants challenged with TuMV-GFP at 5 days postinoculation (dpi). B, Black light photographs of LL and HL plants 5 dpi. C and D, GFP illumination of stem cross-sections at $5 \mathrm{dpi}$ at $\times 12.5$ magnification. $\mathbf{E}$, White light photograph of plants $11 \mathrm{dpi}$. F and $\mathbf{G}$, GFP illumination of stem cross-sections at $10 \mathrm{dpi}$ at $\times 12.5$ magnification. Scale bars: $\mathrm{A}, \mathrm{B}$, and $\mathrm{E}=5 \mathrm{~cm}$ and $\mathrm{C}, \mathrm{D}, \mathrm{F}$, and $\mathrm{G}=200 \mu \mathrm{m}$. 
HL (Fig. 1A and B). When the stems from these plants were sectioned and viewed under a fluorescence microscope, we observed a much higher level of GFP fluorescence in the phloem, xylem, and pith cells of LL-grown plants compared with HLgrown plants (Fig. 1C and D). By $11 \mathrm{dpi}$, we observed that the plants grown under LL had wilted and collapsed while those grown under HL had not yet succumbed to the virus (Fig. 1E). At this time, GFP levels in the stems of HL plants exceeded that of LL plants, suggesting that systemic movement may be simply delayed under HL conditions (Fig. 1F and G).

\section{Virus-induced gene silencing of PSII components reduces $\Phi_{\text {PSII }}$ and increases susceptibility to TuMV-GFP.}

Next, we tested whether impairment of photosystem function would likewise promote TuMV-GFP foci formation in a fashion similar to LL conditions. This was done by silencing genes that regulate key steps of the photosynthetic pathway using the Tobacco rattle virus (TRV) virus-induced gene silencing (VIGS) system and quantitatively measuring the degree of PSII impairment (Burch-Smith et al. 2004). Two genes were chosen from the PSII oxygen-evolving complex (PSII OEC), $P s b O$ and $P s b Q$. $P s b O$ had previously been shown to be important for susceptibility to TMV and Potato virus $X$ (PVX) (Abbink et al. 2002). The ribulose-1,5-bisphosphate carboxylase/oxygenase gene $($ RuBisCo) was selected due to its role in the CalvinBenson cycle. The enzyme phytoene desaturase $(P D S)$ was chosen because it is the first committed step in the carotenoid biosynthetic pathway. Finally, a chloroplast-associated protease, $F t s H$, was selected due to studies linking it to virus infection and defense responses (Gorovits et al. 2007; Seo et al. 2000).

To confirm that the genes were silenced in TRV-infected plants, total protein extracts were blotted against the antibody for PsbO (Fig. 2A). Sodium dodecyl sulfate polyacrylamide gel electrophoresis of total protein from TRV-Empty and RuBisCo-TRV constructs was used to confirm the absence of the highly abundant RuBisCo protein band (Fig. 2B). Plants infected with the PsbQ-TRV construct appeared phenotypically normal under white light, similar to the effect seen by silencing PsbO. However, a commercially available PsbQ antibody was unable to readily detect the protein in control plants and, therefore, we not used to confirm this construct. Plants infiltrated with the FtsH and PDS-TRV constructs exhibited obvious photobleaching phenotypes consistent with previously published results (Kumagai et al. 1995; Ruiz et al. 1998; Saitoh and Terauchi 2002) (Fig. 3C, lower panel).

In an attempt to assess whether there were direct correlations between PSII impairment and numbers of TuMV-GFP foci formed, PSII efficiency was quantitatively measured in TRV-infected plants using a chlorophyll fluorescence imaging system (CFI, Walz, Germany). This instrument enables realtime, nondestructive imaging of PSII efficiency in whole plants (Maxwell and Johnson 2000; Schreiber et al. 1986). The effective quantum yield of PSII ( $\left.\Phi_{\text {PSII }}\right)$ was measured on eight replicate plants once daily for a total of 21 days. The average $\Phi_{\text {PSII }}$ values for each TRV construct were plotted over the course of the experiment (Fig. 3A). White-light photographs and false-color CFI images of the VIGS-silenced plants at 8 and 15 days post-TRV inoculation (dpi-TRV) revealed the extent of PSII impairment (Fig. 3B and C).

There was little net change in $\Phi_{\text {PSII }}$ in the first 6 dpi-TRV regardless of the construct used. The PsbO-TRV plants were the first to show a drop in $\Phi_{\text {PSII }}$ and, throughout the course of the experiment, these plants experienced the most severe impact on $\Phi_{\text {PSII }}$ of any of the constructs tested. The PsbQ-TRV and RuBisCo-TRV plants experienced a moderate and steady decrease in their $\Phi_{\text {PSII }}$ values over the duration of the experiment. The FtsH-TRV and PDS-TRV plants had major changes in
PSII, although the effect was localized to discrete areas of the leaves (Fig. 3C) and the overall impact on the plant was not as severe as in the PsbO-TRV plants. Although FtsH-TRV and PDS-TRV displayed initial decreases in $\Phi_{\text {PSII }}$ similar to the other constructs (at approximately 10 to $16 \mathrm{dpi}-\mathrm{TRV}$, they both later experienced a period of $\Phi_{\mathrm{PSII}}$ recovery, after which the $\Phi_{\text {PSII }}$ values continued to rise until the end of the experiment) (Fig. 3A). Only the TRV-Empty plants did not show any changes in PSII activity (Fig. 3A).

Next, VIGS-silenced plants were challenged with TuMVGFP at either 8 or 15 dpi-TRV. The first time point ( 8 dpiTRV) was chosen because most of the plants had not yet begun to show symptoms of gene silencing, with the exception of PsbO-TRV, which began to exhibit a modest decrease in $\Phi_{\text {PSII }}$ (Fig. 3A and B; Table 1). The second time point (15 dpi-TRV) was chosen because, by this time point, all TRV-silenced plants were showing a reduction in $\Phi_{\text {PSII }}$ (Fig. 3A and C; Table 1). In order to measure changes in TuMV-GFP foci number for each of the plants in relation to each other, a multiple-range analysis of variance (ANOVA) test was run using the number of foci counted on each inoculated leaf. There was no statistical difference in the number of foci between all plants challenged at 8 dpi-TRV ( $P$ value $<0.05)$ (Table 1$)$, though it is worthwhile to note that PsbO-TRV-infected plants tended to have more foci. By 15 dpi-TRV, there was a statistically significant difference in foci number between most of the VIGSsilenced plants compared with the control TRV-Empty plants $(P$ value $<0.05)$ (Table 1). PsbO-, PsbQ-, FtsH-, and RuBisCo-TRV plants had three to four times more TuMV-GFP foci than the PDS-TRV or TRV-Empty plants. Collectively,
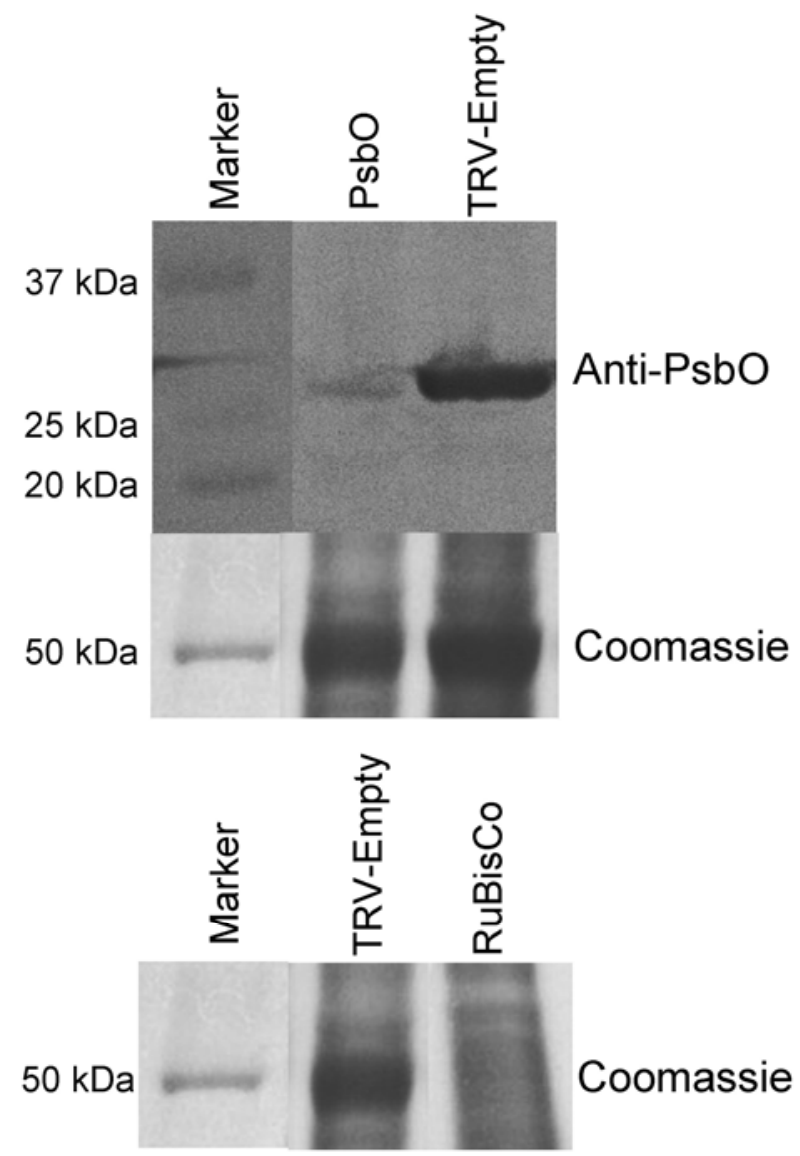

Fig. 2. Gel blot confirmation of Tobacco rattle virus (TRV)-silencing constructs. $\alpha$-PsbO Immunoblot (upper) and Coomassie stained gel (lower). Coomassie stained protein gel demonstrating absence of RuBisCo protein band (approximately50 kDa). Size of markers indicated on left of image. 
A

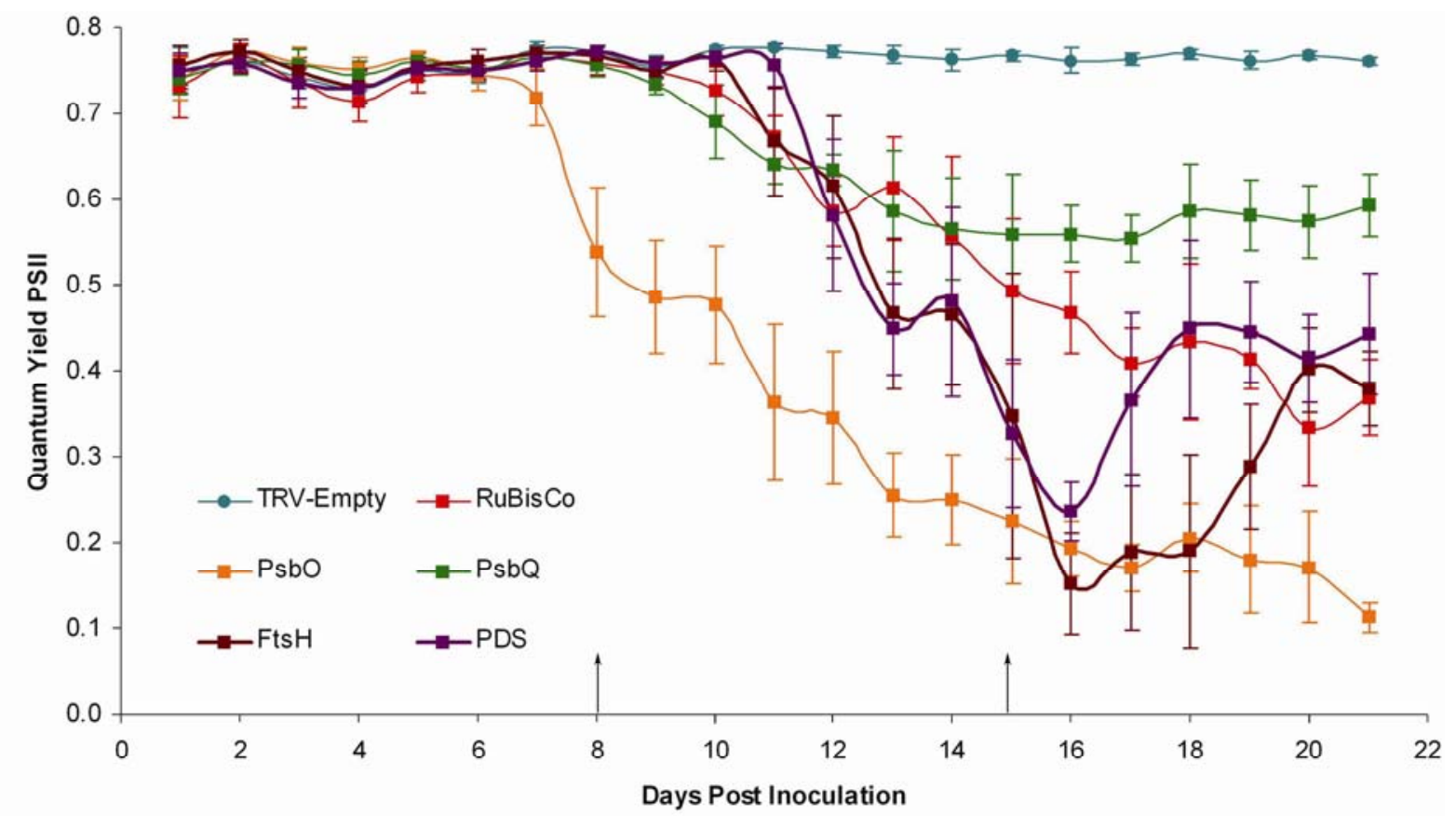

B

TRV-Empty $\quad$ PsbQ

C

\section{$15 \mathrm{dpi}$}

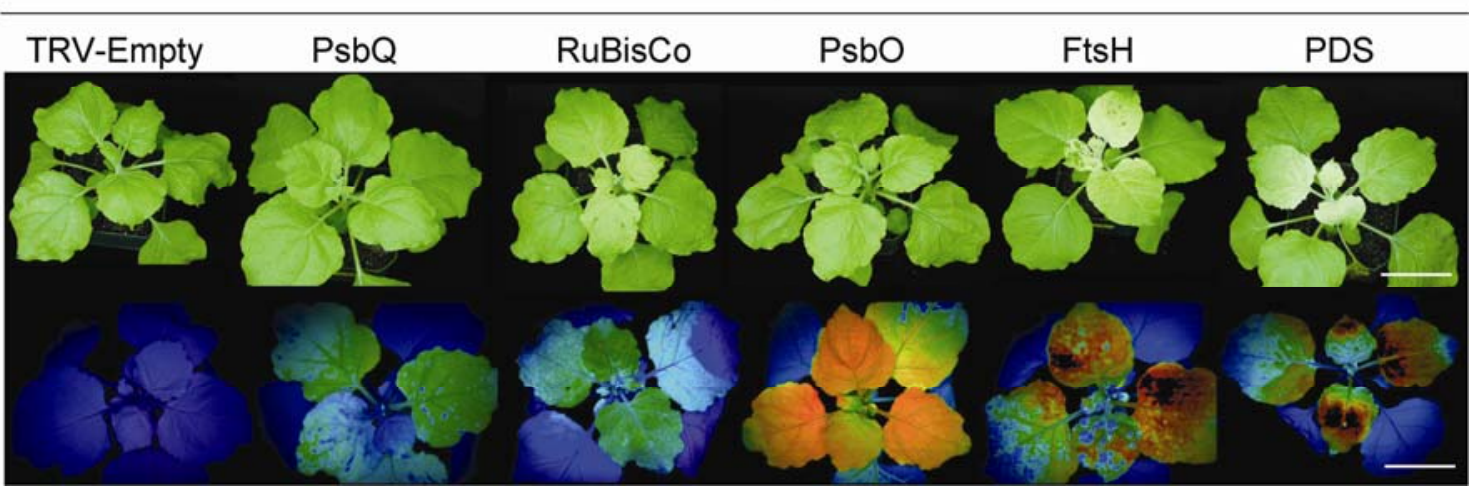

Fig. 3. Changes in quantum yield of photosystem II caused by silencing different components of the photosynthetic pathway. To quantify levels of photosystem impairment, PSII efficiency was measured in Tobacco rattle virus (TRV)-infected plants using a nondestructive chlorophyll fluorescence imaging system. A, Quantum yield of PSII each day post-TRV inoculation. Arrows show days on which plants were challenged with Turnip mosaic virus-green fluorescent protein (TuMV-GFP). Error bars represent standard deviation. B and C, White light (top) and false-colored CFI images (bottom) of phenotypic effect of TRV silencing of photosystem components. Scale bars $=5 \mathrm{~cm}$. Schematic on left indicates the leaves injected with TRV constructs at time point 0 days postTRV inoculation (dpi-TRV) and leaves challenged with TuMV-GFP at 8 and 15 dpi-TRV. Leaves chosen for TuMV-GFP inoculation were used because they were fully expanded and had not begun to senesce. 
these data indicate a relationship between PSII efficiency and the ability of TuMV to establish infection sites. We also noted that TuMV-GFP appeared in systemic tissues of TRV-PsbO-, PsbQ-, FtsH-, and RuBisCo-treated plants earlier than in the mock or TRV-PDS plants (data not shown).

\section{Chemical treatments that decrease the $\Phi_{\text {PSII }}$} in $N$. benthamiana alter host susceptibility.

We next tested whether treatment with chemicals that inhibit PSII efficiency could mimic the effects observed in the VIGS constructs. Norflorazon (NF), a chemical that blocks carotenoid biosynthesis and causes the depletion of chlorophyll, was chosen because it mimicked the effect of the PDS-TRV construct. Lincomycin (Lin), which inhibits protein synthesis from $70 \mathrm{~S}$ ribosomes, was chosen because of its broad impacts on chloroplast function. Leaves were separately treated with NF, Lin, or water (mock), then placed under light at $150 \mu \mathrm{mol} / \mathrm{m}^{-2}$ $\mathrm{s}^{-1}$ for 2 to 5 days. The effective quantum yield of PSII $\left(\Phi_{\mathrm{PSII}}\right)$ was then measured using the CFI system. Mock-treated plants maintained standard levels of $\Phi_{\mathrm{PSII}}$ (between 0.7 and 0.8), whereas plants treated with NF or Lin were severely decreased (Table 2; Fig. 4). Six plants from each chemical and mock treatment were challenged with TuMV-GFP by sap inoculation. The number of foci were counted after 4 days and used for a multiple-range ANOVA. Plants treated with Lin developed two to three times more foci than those treated with NF or water (mock, $P$ value $<0.05$ ) (Table 2). The increased number of
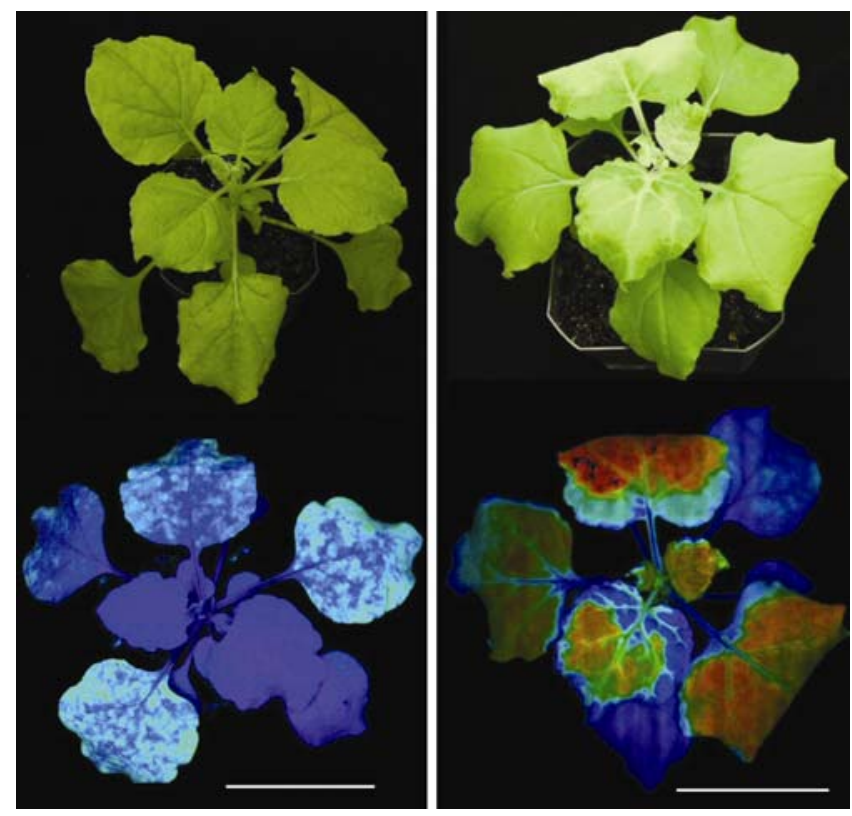

Fig. 4. White light (top) and false-colored CFI images (bottom) demonstrating phenotypic effects of chemical treatments on PSII activity. Left, lincomycin treatment. Right, norflurazon treatment. Scale bars $=5 \mathrm{~cm}$.
TuMV-GFP foci found on Lin-treated plants was similar to that caused by the silencing of the $P s b O, P s b Q, F t s H$, or RuBisCo genes when those plants were challenged with TuMV-GFP on 15 dpi-TRV. Likewise, the mock and NF plants developed an equal number of foci, mirroring the results of silencing the PDS gene. Also consistent with the VIGS study, we observed faster TuMV-GFP systemic movement in Lin-treated plants relative to the mock or NF plants (data not shown).

\section{Rate of foci establishment and systemic movement is altered in PSII-impaired plants.}

The observation that TuMV-GFP moved into systemic tissues more rapidly under conditions of LL or photosystem impairment (Lin) prompted us to carefully measure the rates of cell-to-cell and systemic movement using these two treatments. The assays were performed using time lapse photography and by measur ing the appearance and growth of TuMV-GFP infection foci in inoculated leaves and subsequent movement into systemic tis sues. Lin- and mock-treated plants were challenged with TuMVGFP, then placed under light at $200 \mu \mathrm{mol} / \mathrm{m}^{-2} \mathrm{~s}^{-1}$ during a cycle of $8 \mathrm{~h}$ of light and $16 \mathrm{~h}$ of darkness. Plants were photo graphed every $30 \mathrm{~min}$ for 6 days under black light illumina tion. Virus inoculations were performed either first thing in the morning (after dark adaptation) or late in the afternoon (after light exposure) to assess whether the light cycle influenced foci establishment or systemic movement. The photographic images were assembled into two videos that show the develop ment of viral foci and systemic movement throughout the plant (Supplementary videos). Unexpectedly, we observed that TuMV-GFP foci became visible faster in Lin-treated plants relative to controls. This effect of Lin was more pronounced when plants were challenged in the afternoon compared with the morning. To assess the rate of TuMV-GFP cell-to-cell movement, the diameters of five foci per leaf were measured once per hour from the time they became visible until the end of the experiment. The foci measurements were graphed against the hours postinoculation and the slope of the line was determined. The results showed that, even though TuMV-GFP foci appeared more rapidly in Lintreated plants, there was lit tle difference in the overall rate of foci growth, indicating that viral cell-to-cell movement is not substantially effected by Lin treatment (Fig. 5A and B).

Next, we performed similar time-lapse studies under conditions of light deficiency. Plants were inoculated and main-

Table 2. Quantum yield of photosystem II and levels of susceptibility of chemical treatments to Turnip mosaic virus-green fluorescent protein (TuMV-GFP) challenge ${ }^{\mathrm{z}}$

\begin{tabular}{lcc}
\hline Treatment & RNF & ФPSII \\
\hline Mock & $1.0 \pm 0.43 \mathrm{a}$ & $0.748 \pm 0.005$ \\
Norflorazon & $0.95 \pm 0.48 \mathrm{a}$ & $0.172 \pm 0.042$ \\
Lincomycin & $2.05 \pm 0.75 \mathrm{~b}$ & $0.113 \pm 0.044$ \\
\hline
\end{tabular}

${ }^{\mathrm{z}}$ Relative number foci (RNF) were counted 4 days post-TuMV-GFP challenge. Statistically significant groups are indicated by a and $\mathrm{b}$.

Table 1. Levels of susceptibility of Tobacco rattle virus (TRV)-silenced plants to Turnip mosaic virus-green fluorescent protein (TuMV-GFP) challenge 8 and 15 days post-TRV inoculation $(\mathrm{dpi})^{\mathrm{z}}$

\begin{tabular}{|c|c|c|c|c|}
\hline \multirow[b]{2}{*}{ TRV construct } & \multicolumn{2}{|c|}{8 dpi TRV } & \multicolumn{2}{|c|}{15 dpi TRV } \\
\hline & RNF & ФPSII & RNF & ФPSII \\
\hline PsbO-TRV & $2.46 \pm 0.56 \mathrm{a}$ & $0.538 \pm 0.075 \mathrm{a}$ & $4.00 \pm 1.70 \mathrm{a}$ & $0.225 \pm 0.073 \mathrm{a}$ \\
\hline PsbQ-TRV & $1.16 \pm 1.18 \mathrm{a}$ & $0.756 \pm 0.013 b$ & $4.20 \pm 1.98 \mathrm{a}$ & $0.560 \pm 0.070 b$ \\
\hline RuBisCo-TRV & $1.19 \pm 0.88 \mathrm{a}$ & $0.759 \pm 0.013 b$ & $3.48 \pm 1.26 \mathrm{a}$ & $0.494 \pm 0.084 b$ \\
\hline FtsH-TRV & $1.80 \pm 0.54 \mathrm{a}$ & $0.769 \pm 0.004 b$ & $3.80 \pm 2.86 \mathrm{a}$ & $0.348 \pm 0.167 \mathrm{a}$ \\
\hline PDS-TRV & $1.31 \pm 1.16 \mathrm{a}$ & $0.772 \pm 0.007 b$ & $1.36 \pm 0.86 b$ & $0.328 \pm 0.086 \mathrm{a}$ \\
\hline TRV-Empty & $1.00 \pm 0.90 \mathrm{a}$ & $0.772 \pm 0.006 \mathrm{~b}$ & $1.00 \pm 0.72 b$ & $0.767 \pm 0.007 \mathrm{c}$ \\
\hline
\end{tabular}

${ }^{\mathrm{z}}$ Relative number foci (RNF) were counted 4 days post-TuMV-GFP challenge. Statistically significant groups are indicated by a and b. 


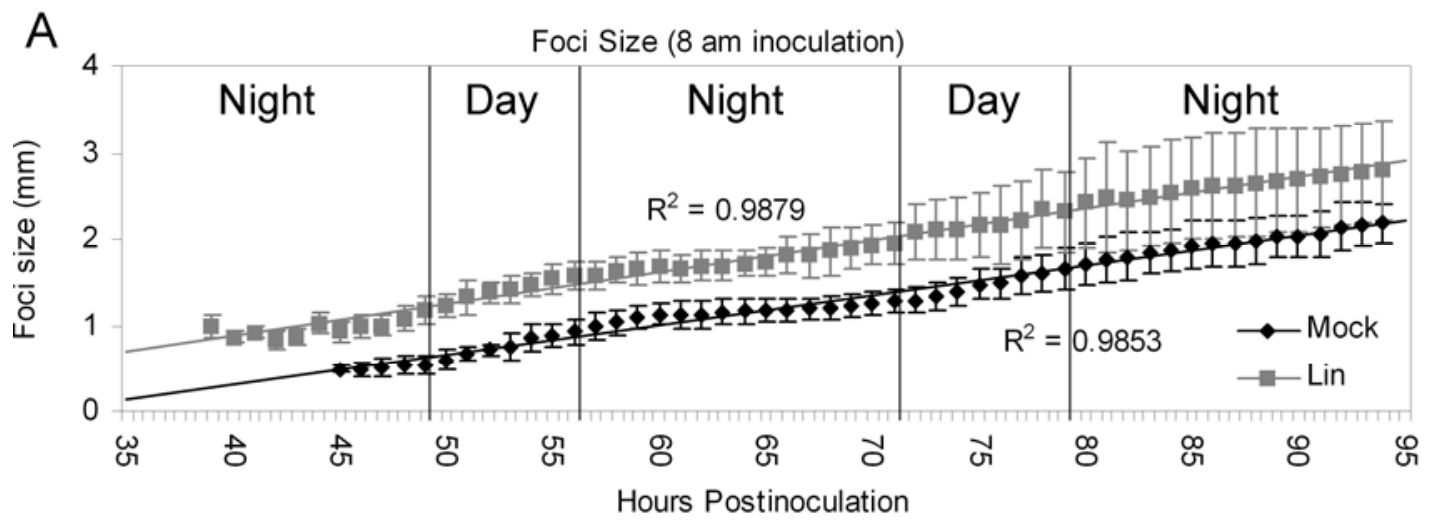

B

Foci Size (4 pm inoculation)

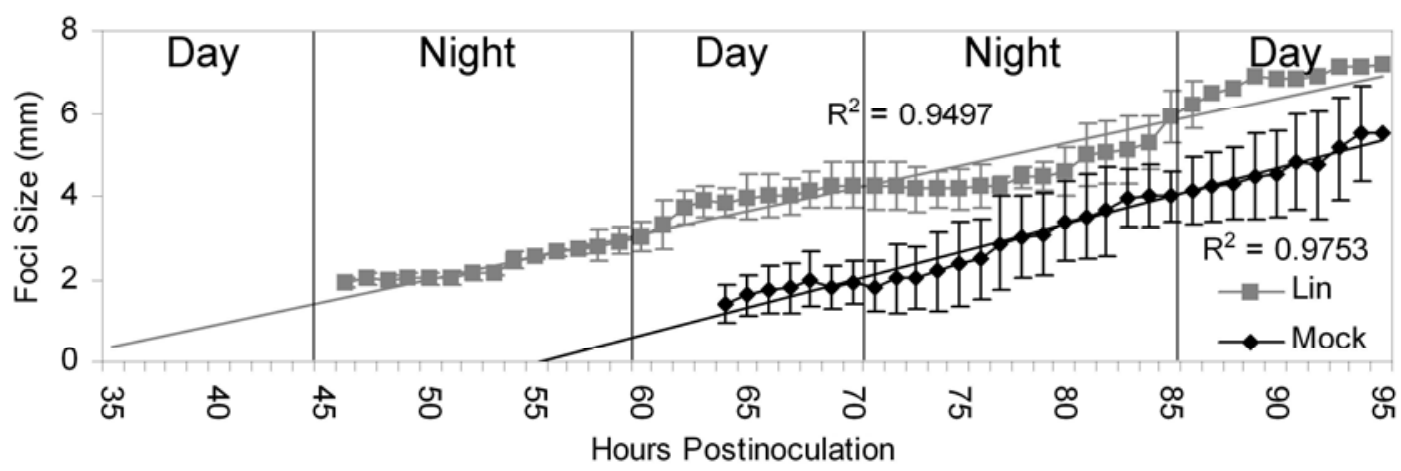

Fig. 5. Quantification of the rate of Turnip mosaic virus-green fluorescent protein (TuMV-GFP) foci growth on mechanically inoculated Nicotiana benthamiana plants. Leaves were treated topically with lincomycin (Lin) or water (Mock) 2 days prior to TuMV-GFP challenge. Plants were virus challenged at A, 8:00 a.m. or B, 4:00 p.m. The size of five foci were measured (in millimeters) every hour after TuMV-GFP inoculation and graphed to determine the rate of foci growth. Slope of the line is shown as an $R^{2}$ value. Error bars represent standard deviation. Note: error bars for the final measurements in the Lintreated plants in $5 \mathrm{~b}$ are very small $(>0.1 \mathrm{~mm})$ and, therefore, cannot be seen. Results are representative of three independent experiments.

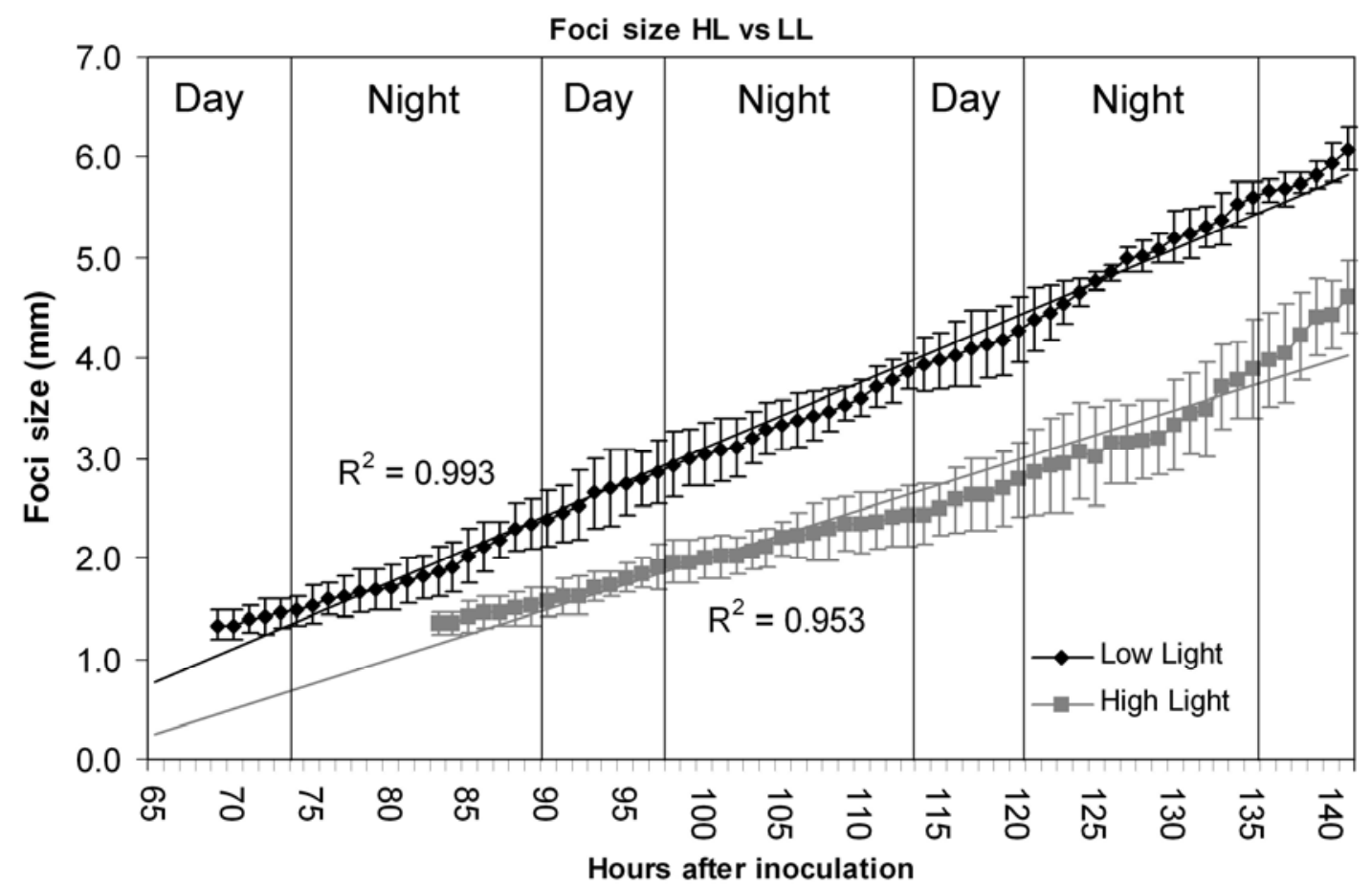

Fig. 6. Quantification of the rate of Turnip mosaic virus-green fluorescent protein (TuMV-GFP) foci growth on mechanically inoculated Nicotiana benthamiana plants. Plants were virus challenged at 4:00 p.m. and placed under $20 \mu \mathrm{mol} / \mathrm{m}^{-2} \mathrm{~s}^{-1}$ (low light) (LL) and $300 \mu \mathrm{mol} / \mathrm{m}^{-2} \mathrm{~s}^{-1}$ (high light) (HL). The size of three foci were measured (in millimeters) every hour after TuMV-GFP inoculation and graphed to determine the rate of foci growth. Slope of the line is shown as an $R^{2}$ value. Error bars represent standard deviation. Results are representative of three independent experiments. 
tained under LL $\left(20 \mu \mathrm{mol} / \mathrm{m}^{-2} \mathrm{~s}^{-1}\right)$ or $\mathrm{HL}\left(300 \mu \mathrm{mol} / \mathrm{m}^{-2} \mathrm{~s}^{-1}\right)$ conditions. LL relative to HL had essentially the same effect as Lin compared with mock (Fig. 6). Foci appeared more rapidly under LL and TuMV-GFP exhibited faster systemic movement. Again, foci growth rates indicated little difference in the rate of cell-to-cell movement (Fig. 6). Based on the foci diameter and the rates of systemic movement, the data collectively reveal that both LL and Lin treatment speed up the TuMV-GFP infection cycle by approximately $15 \mathrm{~h}$ relative to controls.

\section{The effect of chloroplast impairment on SA levels.}

SA is a chloroplast-derived plant hormone that acts as an upstream activator for plant defense responses (Garcion et al. 2008; Wildermuth et al. 2001). Therefore, we reasoned that the observed impacts of light and PSII efficiency on virus susceptibility could be related to impairment of defenses either through a reduction in SA levels or a block in SA-mediated signaling. First, we tested whether TuMV-GFP infection induced SA production, as evidence that SA-mediated pathways are activated under normal infection conditions. The amount of SA in plants challenged with TuMV-GFP (virus) and water (mock) was quantified in systemically infected tissues 9 dpi. SA levels were roughly fourfold higher in TuMV-GFP-infected leaves than those treated with water (Fig. 7A). Next, we quantified the amount of SA produced in Lin- and water (mock)treated plants. The steady-state SA levels after Lin treatment were fourfold higher than their mock-treated counterparts (Fig. 7B). These results demonstrate that TuMV-GFP normally induces SA defenses but also show that proper chloroplast function (i.e., Lin treatment) is not necessary for SA accumulation.

\section{Pathogen response-1 expression is induced by $\mathrm{SA}$ in Lin-treated plants.}

To assess whether downstream SA signaling was effected by chloroplast impairment or light deficiency, we used quantitative real-time reverse-transcriptase polymerase chain reaction (qRT-PCR) to examine the induction of the well-known SA
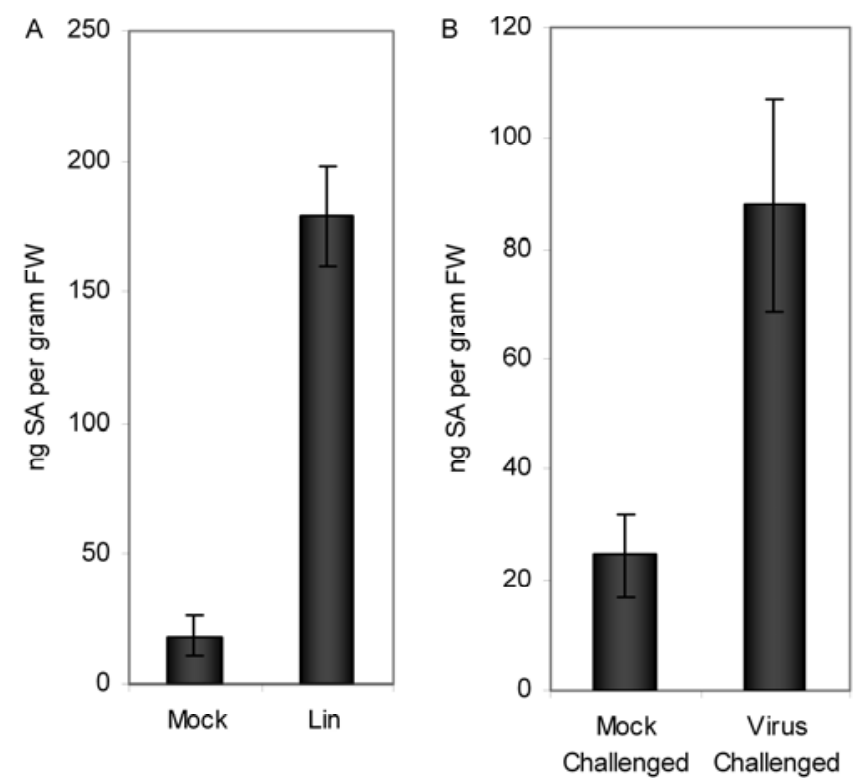

Fig. 7. Quantification of salicylic acid (SA) levels in virus-infected and chemically treated Nicotiana benthamiana. A, Plants were mechanically inoculated with water (Mock Challenged) or TuMV-GFP (Virus Challenged) and grown under light at $100 \mu \mathrm{mol} / \mathrm{m}^{-2} \mathrm{~s}^{-1}$ for 10 days before being harvested for SA extraction. B, Plants were treated with water (Mock) or $1.25 \mathrm{mM}$ lincomycin (Lin) and grown under light for $100 \mu \mathrm{mol} / \mathrm{m}^{-2} \mathrm{~s}^{-1}$ for 3 days before being harvested for SA extraction. Error bars represent standard deviation. Results are representative of three independent experiments. marker gene, pathogen response-1 $(P R-1)$. Nontreated $N$. benthamiana leaves and leaves treated with Lin for $72 \mathrm{~h}$ were subsequently treated with $5 \mathrm{mM} \mathrm{SA}$. After $24 \mathrm{~h}$, leaf tissues were harvested for RNA extraction. $P R-1$ expression was induced over 100-fold in -Lin/+SA plants and over 250-fold in + Lin/+SA-treated leaves (Fig. 8). Similarly, plants treated with SA in the dark showed levels of $P R-1$ gene induction similar to those treated with SA in the light. This is in contrast to previous reports in Arabidopsis thaliana that indicate a lack of $P R-1$ induction under dark conditions (Genoud et al. 2002). The induction of $P R-1$ gene expression in both + Lin/+SA plants and dark-grown -Lin/+SA plants demonstrates that SA-mediated defense signaling (i.e., $P R-1$ expression) is not impaired by these treatments.

\section{Pretreatment with SA does not provide resistance to TuMV-GFP.}

To confirm whether SA could influence host susceptibility to TuMV-GFP, we tested whether SA treatment could induce protection via SAR. SAR is known to enhance disease resistance by promoting cellular defense responses through a mechanism known as "priming" (Cameron et al. 1999; Conrath et al. 2001; Kauss and Jeblick 1995; Kauss et al. 1992, 1993; Kohler et al. 2002). Leaves were treated with $5 \mathrm{mM}$ SA for 24, 48, 72, and $120 \mathrm{~h}$ before challenge with TuMV-GFP. A regression analysis demonstrated that there was no statistical difference in the number of foci on nontreated leaves and those challenged at the different time points following SA treatment $(P<0.5)$ (Fig. 9). Therefore, induction of SA-mediated defenses did not

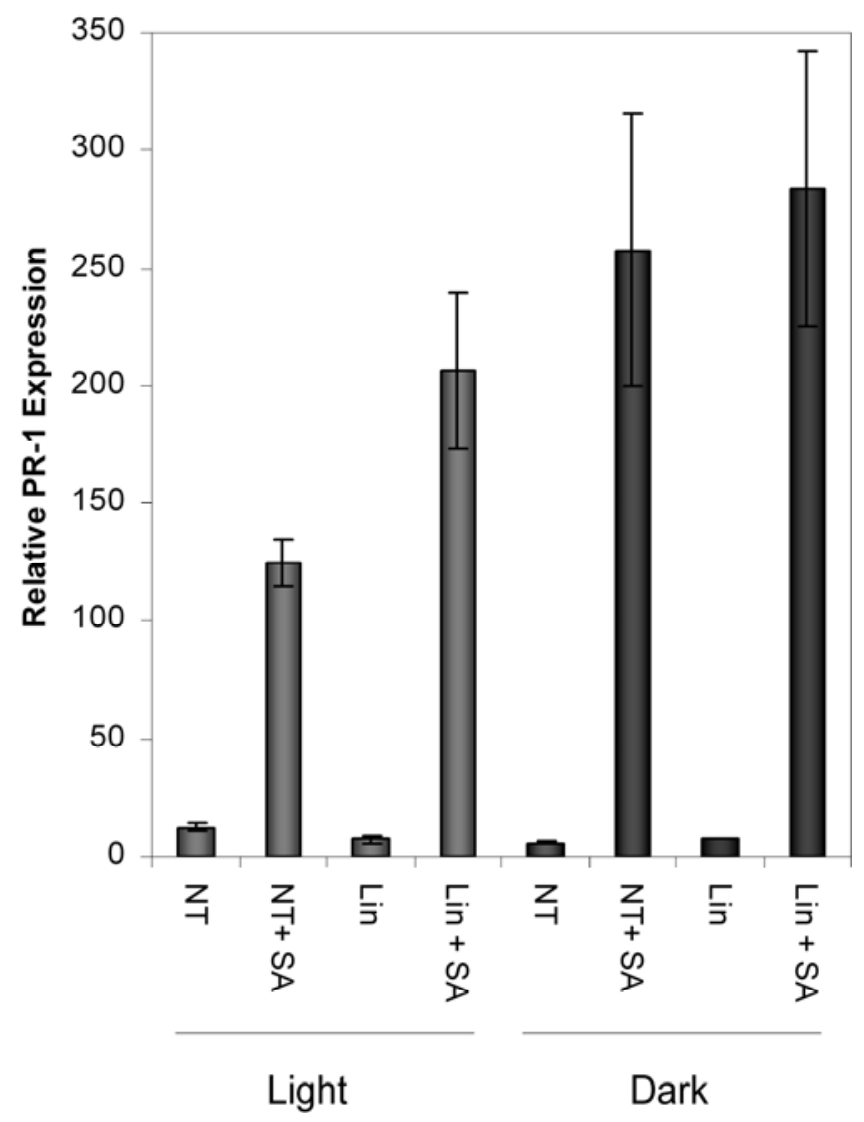

Fig. 8. Determination of pathogen response-1 (PR-1) expression levels by quantitative reverse-transcription polymerase chain reaction. Values represent the average of three biological replicates and three technical replicates. Expression levels were normalized to actin. NT = nontreated, $\mathrm{SA}=\mathrm{SA}$ treated, and Lin = lincomycin treated. Error bars represent standard deviation. 
influence TuMV-GFP foci number, even when known defense markers were highly expressed (Fig. 7) (Murphy and Carr 2002).

\section{DISCUSSION}

One of the most universal symptoms of virus infection is chlorosis, which results from cytopathic effects on chloroplast structure or function (Hatta and Mathews 1974; Hatta et al. 1973; Prod'homme et al. 2003; Wei et al. 2009). A growing body of biochemical and molecular evidence suggests that viruses may directly target chloroplasts through a coordinated and broad-based attack. Viral infection has been shown to directly impact PSII efficiency and affect photosynthesis (Lehto et al. 2003; Reinero and Beachy 1989). Recent studies on global gene expression of virus-infected plants have revealed that plant viruses commonly repress the expression of numerous nuclear-encoded chloroplast genes (Dardick et al. 2007; Shimizu et al. 2007; Yang et al. 2007). Further, a number of reports have found that some viral proteins directly interact with chloroplast proteins (Supplementary Table S1). Consistent with this, we have found an abundance of chloroplast proteins interacting with numerous Potyvirus proteins from large-scale yeast two-hybrid screens (unpublished data). Together, these studies indicate that at least some plant viruses allocate significant resources to disrupting or modifying chloroplast structure or function; however, the reasons why remain unknown.

Several studies have linked specific photosystem genes to the promotion of host susceptibility. Abbink and associates (2002) showed that silencing the photosystem II component PsbO led to increased foci size and foci numbers of both TMV-GFP and PVX-GFP. Similarly, Jimenez and associates (2006) showed that silencing the photosystem I protein PsaK, which interacts with the Potyvirus replication protein CI, also led to increased numbers of Plum pox virus-GFP foci. In a third example, a chloroplast rhodanese sulfur transferase called NRIP1 was found to directly interact with the TMV helicase (p50) and the resulting complex was required for recognition by the tobacco resistance gene $N$ (Caplan et al. 2008). Although, collectively, this data suggests that targeting of chloroplast proteins by viruses may represent a broad strategy to promote host susceptibility, many of these studies remain incomplete, and the functions or mechanisms by which these chloroplast

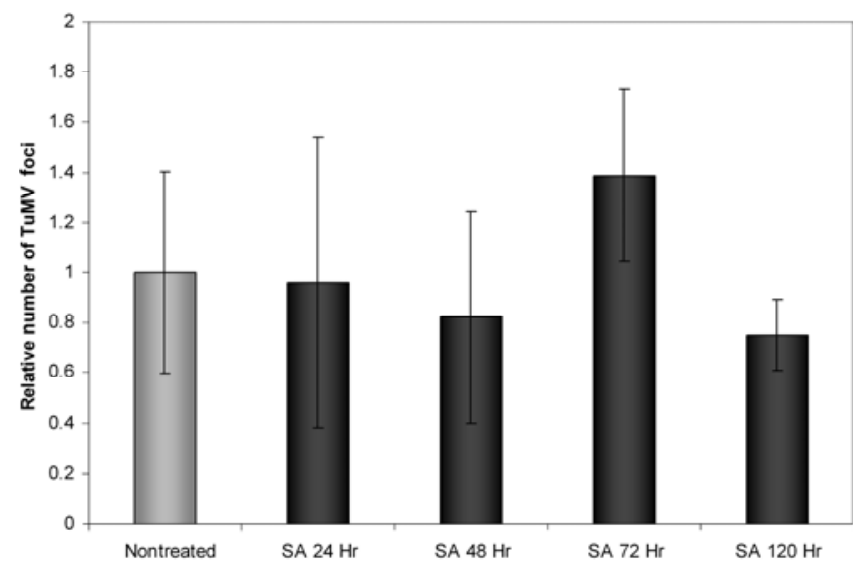

Fig. 9. Host susceptibility to Turnip mosaic virus-green fluorescent protein (TuMV-GFP) is not responsive to pretreatment with salicylic acid (SA). Plants were topically treated with $5 \mathrm{mM} \mathrm{SA}$, then challenged with TuMV-GFP after 24, 48, 72, and $120 \mathrm{~h}$. Average numbers of foci per leaf on the SA-treated plants were determined 4 days post-TuMV-GFP challenge and are shown relative to the number of foci on nontreated plants (set to 1). Error bars represent standard deviation. Results representative of three independent experiments. proteins contribute to susceptibility remain unknown. A number of researchers have proposed that the chloroplast likely plays a critical role in host defense responses and these interactions may represent viral attempts to thwart defense signaling, though little direct evidence exists to support this hypothesis (Abbink et al. 2002; Genoud et al. 2002; Griebel and Zeier 2008; Lehto et al. 2003).

In addition to chloroplast function, light has also long been thought to be an important mediator of viral pathogenesis. A number of older reports have suggested that either the quantity of light, photoperiod, or time of day of virus inoculation can influence host susceptibility, though little attention has been given to this subject in recent years (Bawden and Roberts 1947, 1948; Helms 1965; Matthews 1953a and b; Wiltshire 1956; Yarwood 1956). This phenomenon has also been linked to SA-mediated defense signaling. Several studies in $A$. thaliana have found that SA-mediated defenses, including SAR and the HR, require the photoreceptors PhyA and PhyB, thus resulting in a light-dependent defense signal (Genoud et al. 2002; Griebel and Zeier 2008). Light has also been shown to play a key role in host susceptibility to bacterial pathogens via SA signaling (Zeier et al. 2004). Whether inhibition of SAmediated defenses underlies the influence of light and chloroplast function on viral infection remains unknown.

Here, we evaluated the impacts of light quantity and targeted photosystem impairments on the ability of TuMV-GFP to infect $N$. benthamiana. Using a combination of imaging technologies, we tested whether light quantity or photosystem impairment could impact i) the ability of TuMV-GFP to establish infection sites (i.e., the number of GFP foci formed on inoculated leaves), ii) virus cell-to-cell movement, iii) the pattern and timing of systemic spread, and iv) rate of symptom development.

Silencing four of five chloroplast proteins via VIGS led to increased numbers of TuMV-GFP foci relative to controls. Likewise, the chloroplast protein synthesis inhibitor Lin increased both foci number and rate of systemic movement. Silencing of the chlorophyll biosynthesis gene PDS or application of the chlorophyll biosynthesis inhibitor NF had no effect. Collectively, these data suggest that individual photosynthetic proteins themselves are probably not responsible for changes in host susceptibility; rather, it is influenced by more general features of photosystem or chloroplast function.

Interestingly, light deficiency demonstrated effects on host susceptibility strikingly similar to targeted photosystem impairment. Our results showed that plants grown under LL also displayed an increase in the number of infection foci and rate of systemic movement. Balachandran and Osmond (1994) observed a similar effect when they infected $N$. tabacum with TMV under HL and LL conditions. They found that plants grown in LL showed an acceleration of symptom development when challenged with TMV and concluded that biotic stress following TMV infection leads to exaggerated sensitivity to photoinhibition and an increased rate of leaf senescence. Our studies are consistent with their results and go on to offer a possible explanation as to how photoinhibition can lead to the accelerated senescence of virus-infected plants. Using time-lapse photography, we demonstrated that light deficiency (and chemically induced photosystem impairment) led to an increased rate of viral foci development and more rapid systemic movement throughout the plant. Further, we observed a high level of necrosis on virus-challenged plants grown under HL. In a report by Kim and associates (2008), veinal necrosis in A. thaliana was associated with the HR during TMV virus infection in plants carrying the TuNI locus and grown under high light compared with those grown in the shade. It is currently unknown whether TuMV-induced necrosis observed in N. benthamiana under HL is due to a similar phenomenon. 
The time of day plants were challenged (i.e., at the beginning or end of the light cycle) likewise influenced the rate of TuMVGFP foci appearance. All $N$. benthamiana inoculated with TuMV-GFP in the afternoon (after exposure to light just before a dark period) showed a lag in the onset of foci development when compared with plants challenged in the morning (after a dark period, just prior to light exposure). The delay in disease establishment $(7 \mathrm{~h}$ ) was shorter in Lin-treated plants (46 h postinoculation [hpi] afternoon, 39 hpi morning) compared with mock plants, where foci development was delayed by $20 \mathrm{~h}$ (64 hpi afternoon, 44 hpi morning). These results confirm previous work by Helms and McIntyre (1967) and suggest that, after a period of dark adaptation, the virus is able to infect plants much more rapidly than it does after a period of light exposure. Interestingly, treatment with Lin was able to at least partially mitigate this delay. This may be due to the ability of Lin to block the repair of photosynthetic machinery, which would indicate that the photosynthetic or energy-producing functions of the chloroplast are essential for the plant's defense mechanisms. At this point, it is uncertain whether changes in the level of virus susceptibility are caused by light itself, or are instead due to metabolic or developmental impairments resulting from the lack of energy production by the chloroplast. However, given that the PDS-TRV construct and NF treatment both act upstream of photosynthesis by blocking carotenoid biosynthesis and do not cause an increase in $N$. benthamiana susceptibility to TuMVGFP, it seems unlikely that the absence of photosynthate products such as starch and sucrose are responsible for changes in host susceptibility. Therefore, this work indicates that impairment of photosynthesis either through light deficiency, dark adaptation, or targeted chloroplast disruption allows TuMV-GFP to establish an infection much more rapidly than is possible in control plants.

Because the SA-mediated host defense pathways have previously been shown to be light dependent and SA is likely synthesized within chloroplasts, we hypothesized that the observed changes in host susceptibility could be due to impaired SA defense signaling (Antoniw and White 1980; Gaffney et al. 1993; Garcion et al. 2008; Genoud et al. 2002; Genoud et al. 2002; Klessig and Malamy 1994; Malamy et al. 1990; Malamy et al. 1992; Raskin 1992; Strawn et al. 2007; Uknes et al. 1993; Ward et al. 1991; White 1979). By measuring total SA accumulation in mock- and Lin-treated $N$. benthamiana, we found that SA accumulates to high levels in both conditions, indicating that SA deficiency is not likely causing the observed changes in host susceptibility. SA levels in Lin-treated plants were fourfold higher than their mock-treated counterparts, suggesting that there is an important relationship between photosynthesis and levels of SA accumulation (Genoud et al. 2002; Griebel and Zeier 2008; Zeier et al. 2004). This result suggests that, although $\mathrm{SA}$ is synthesized in the chloroplast, efficient chloroplast function is not required for its accumulation. Rather, impairment of photosynthesis appears to enhance the accumulation of SA.

Consistent with the higher levels of SA, we also found that $P R-1$ induction following SA treatment is not impaired in Linor dark-treated plants. This is consistent with a previous report by Genoud and associates (2002) that expression of $P R-1$ is not modified by a reduction in the number of active chloroplasts. Finally, direct application of SA did not lead to a decrease in the numbers of TuMV-GFP infection foci, indicating that induction of SA-mediated defenses does not likely account for the observed light- and photosystem-dependent changes in $N$. benthamiana susceptibility. It is important to emphasize, however, that these data do not entirely exclude a role for SA because it is possible that SA defenses are already maximal in $N$. benthamiana and that pretreatment with SA cannot further enhance the effectiveness of the SA response that is normally triggered by TuMV-GFP during the natural course of infection. SA-deficient plants such as NahG overexpression or sid2 mutants would need to be tested to rule out a role for SA.

Though we have focused much of our attention on SAmediated defenses, there are a number of other host defense pathways that could also be affected by chloroplast impairment. RNA silencing, JA, and ET are examples of potential antiviral defense pathways that act independently of SA. It is possible that one of these other defense pathways may be impaired by insufficient light or disruption of photosynthesis.

An alternative hypothesis that could explain our results is that light and chloroplast function influence the ability of plant viruses to establish replication centers. Viral RC associated with organelle membranes such as the chloroplast, endoplasmic reticulum, and peroxisome have been identified recently (McCartney et al. 2005; Prod'homme et al. 2003; Reichel and Beachy 1998; Wei et al. 2009). Wei and associates (2010) recently reported that TuMV specifically utilizes the chloroplast outer envelope to establish RC (Wei et al. 2009). In terms of location, the chloroplast outer envelope is ideal for viral replication or assembly because it contains all of the components needed for transcription and translation as well as a large excess of ribosomes (Ellis and Hartley 1974). Consequently, the changes we observed in $N$. benthamiana susceptibility to TuMVGFP may be associated with the ability of the virus to co-opt chloroplast membranes or proteins which are needed to establish replication complexes (Abbink et al. 2002; Seo et al. 2000; Wei et al. 2009).

In summary, we cannot rule out the possibility that light depletion as well as specific VIGS and chemical-induced photosystem impairments tested here influence host susceptibility through distinct mechanisms. However, our observations that these treatments lead to very similar impacts on the number and timing of TuMV-GFP foci establishment, along with similar previous reports that such changes influence susceptibility to a broad range of viruses, suggests that a common mechanism may be responsible (Bawden and Roberts 1947, 1948; Cheo 1971; Helms 1965; Helms and McIntyre 1967; Matthews 1953a and b; Wiltshire 1956; Yarwood 1956). Having largely ruled out SAmediated defense as the underlying mechanism leads us to believe that this phenomenon may represent a fundamental aspect of virus-host interactions that has yet to be described.

\section{MATERIALS AND METHODS}

\section{Plant material.}

$N$. benthamiana plants were grown in a Conviron E7/2 growth chamber at $20^{\circ} \mathrm{C}$ with an 8-h day and 16-h night photoperiod under various light conditions in Metro Mix soil (Sun Gro, Bellevue, WA, U.S.A.).

\section{Construct preparation.}

To downregulate expression of photosynthesis-related genes, TRV RNA2 vector (Burch-Smith 2004) with a pENTR/D-topo cassette (Invitrogen, Carlsbad, CA, U.S.A.) was used. RT-PCR using the SuperScript III kit (Invitrogen) amplified DNA fragments from $N$. benthamiana RNA. Primers used for RT-PCR are as follows: PsbO forward (5'-TGTCGTCTCAGGAGCAA ATGCTGA-3'), PsbO reverse (5'-ATGCAACAGCGTTGTCA TAGCCAG- $3^{\prime}$ ), PsbQ forward (5'-ACTGTGTTGGATGGTCA GCTCTGT-3'), PsbQ reverse (5'-TTTCCAGTCAGGTCCTG GAGCTTT-3'), RuBisCo forward (5'-AGTCAGGTGTGGCC ACCAATTAAC-3'), RuBisCo reverse (5'-AGTGGTTGGGAT GAGGGTGAATGT-3'), FtsH forward (5'-TGAGGGATTTGT TCGAGAAGGCGA-3'), FtsH reverse (5'-ACCAGCTTGGCC TCGAGGAATTAT-3'), PDS forward (5'-CACCAGCTAAGC CGTTGAAGGTCGT-3'), and PDS reverse (5'-ATCCGGTAT 
GCCCTGTTTCCTCTA-3'). PCR-amplified fragments of the target genes were separately cloned into the Gateway cassette in the TRV-PENTR/D vector and transformed into Escherichia coli DH5 $\alpha \mathrm{MCR}$. Positive E. coli colonies were then transformed into Agrobacterium tumefaciens GV3101.

\section{TRV inoculation.}

$N$. benthamiana plants at the four- to six-leaf stage were syringe infiltrated with Agrobacterium spp. containing a 1:1 mixture of TRV RNAs 1 and 2. Luria-Bertani broth cultures $(2 \mathrm{ml})$ with kanamycin at $50 \mathrm{mg} / \mathrm{liter}$ and gentamicin at $50 \mathrm{mg} / \mathrm{liter}$ were grown for 16 to $20 \mathrm{~h}$, with shaking, at $25^{\circ} \mathrm{C}$. When cultures became turbid, they were spun down for $5 \mathrm{~min}$ at 4,000 $\mathrm{rpm}$. The supernatant was poured off and the cells were resuspended in $2 \mathrm{ml}$ of inoculation buffer $\left(10 \mathrm{mM} \mathrm{MgSO}_{4}\right.$ and 100 $\mu \mathrm{M}$ acetosyringone). Cells were allowed to shake for another 4 $\mathrm{h}$ at $25^{\circ} \mathrm{C}$ while $N$. benthamiana plants were dark adapted. Plants were inoculated with equal parts RNA1 and RNA2 by syringe infiltration.

\section{TuMV-GFP inoculation.}

$N$. benthamiana plants were challenged with sap inoculation of TuMV-GFP. Sap inoculum was obtained by grinding $N$. benthamiana tissue that had been systemically infected with TuMV-GFP in a $0.05 \mathrm{mM}$ borate buffer ( $\mathrm{pH} 7.5)$. Leaves were dusted with Carborundum powder, then gently rubbed with $100 \mu$ of sap slurry. The numbers of foci were counted under black light illumination 4 days after TuMV-GFP inoculation.

\section{Chlorophyll fluorescence imaging.}

Chlorophyll fluorescence from whole plants was monitored using a Maxi-Imaging-PAM Chlorophyll Fluorometer (Walz, Effeltrich, Germany). The effective quantum yield of photosystem II $\left(\Phi_{\mathrm{PSII}}\right)$ was recorded using an actinic light illumination.

\section{Time-lapse photography.}

Plants were grown in a Conviron growth chamber at $20^{\circ} \mathrm{C}$ with a $8 \mathrm{~h}$ of light and $16 \mathrm{~h}$ of darkness. Six black-light fixtures were set up around the plants and kept on constant illumination. Light intensity during the Lin or mock experiment was set to 200 and $20 \mu \mathrm{mol} / \mathrm{m}^{-2} \mathrm{~s}^{-1}$ (LL) and $300 \mu \mathrm{mol} / \mathrm{m}^{-2} \mathrm{~s}^{-1}$ (HL) during the LL and HL experiment. Photographs of plants for the timelapse photography experiment were captured every $30 \mathrm{~min}$ using a Canon EOS 5D digital camera and a 100-mm macro lens, f/2.8. White balance was set for 10,000 Kelvin, with a 25 -s exposure time, ISO 400 , and $f / 16$. Leaf temperature was measured using a Raytek Raynger ST series noncontact thermometer (model 60/80; Raytek, Santa Cruz, CA, U.S.A).

\section{Microscopic analysis.}

Stems from TuMV-GFP-infected plants were sectioned using a razor blade and accumulation of GFP was detected using a Zeiss Axiophot fluorescent microscope. Images were recorded using an Olympus DP71digital camera.

\section{Chemical treatments.}

Chemicals were applied to mature $N$. benthamiana leaves using a small paint brush. Nontreated leaves were painted with water, while chemically treated leaves were treated with either with $75 \mu \mathrm{M}$ NF or $1.25 \mathrm{mM}$ Lin. Chemical and nontreated leaves were then exposed to light at $150 \mu \mathrm{mol} / \mathrm{m}^{-2} \mathrm{~s}^{-1}$ to induce photoinhibition.

\section{RNA extraction and real-time qPCR.}

$N$. benthamiana tissue was flash frozen under liquid nitrogen, then ground into a fine powder. RNA was extracted using TRIzol (Invitrogen) according to the manufacturer's instructions, with slight modifications. Briefly, $300 \mu \mathrm{l}$ of TRIzol reagent was added to $100 \mathrm{mg}$ of ground tissue. Tubes were vortexed briefly, then spun for $5 \mathrm{~min}$ at $12,000 \times g$ at $4^{\circ} \mathrm{C}$. The supernatant was removed to a new tube, where $80 \mu \mathrm{l}$ of chloroform was added. Tubes were vortexed and samples were incubated at room temperature for $3 \mathrm{~min}$, then spun as before. The upper phase was removed to a new tube and $100 \mu \mathrm{l}$ of a salt solution $(0.4 \mathrm{M}$ sodium citrate and $0.6 \mathrm{M} \mathrm{NaCl}$ ) was added with $200 \mu \mathrm{l}$ of cold isopropanol. Samples were incubated at $-20^{\circ} \mathrm{C}$ for $1 \mathrm{~h}$, then centrifuged for $10 \mathrm{~min}$ at $16,000 \times g$ at $4^{\circ} \mathrm{C}$. The supernatant was discarded and the pellet resuspended in $90 \mu \mathrm{l}$ of RNase-free water. Samples were then treated with DNase (NEB, Ipswich, MA, U.S.A.) by adding $10 \mu \mathrm{l}$ of DNase buffer and $2 \mu \mathrm{l}$ of DNase enzyme per reaction. The samples were incubated in a $37^{\circ} \mathrm{C}$ water bath for $10 \mathrm{~min}$. The enzyme was heat killed for 10 min at $65^{\circ} \mathrm{C}$. Finally, RNA was purified using the RNA Clean \& Concentrator-25 kit (Zymo Research, Orange, CA, U.S.A.) according to the manufacturer's instructions.

\section{Real-time qPCR.}

Reactions were performed in the ABI Prism 7900HT sequence detector (Applied Biosystems, Foster City, CA, U.S.A.). The real-time assay was performed using SuperScript III Platinum SYBR Green One-Step qRT-PCR kit (Invitrogen). The qRT-PCR reagent $(13 \mu \mathrm{l})$ was added to $2 \mu \mathrm{l}$ of total RNA. The $15-\mu$ assay contained $1 \times$ SYBR Green reaction mix (includes $0.2 \mathrm{mM}$ each $\mathrm{dNTP}$ and $3 \mathrm{mM} \mathrm{MgSO} 4$ ), $200 \mathrm{nM}$ each primer, and $500 \mathrm{nM}$ Rox reference dye. PR-1 forward was 5'GCCCAAAACTCTCAACAAGACTA-3' and PR-1 reverse was 5'-CTTAACCCTAGCACATCCAACAC-3'. Rox was used as a passive dye for assay volume normalization. qRT-PCR was carried out at $50^{\circ} \mathrm{C}$ for $5 \mathrm{~min}, 95^{\circ} \mathrm{C}$ for $5 \mathrm{~min}$, and $40 \mathrm{cy}-$ cles of $95^{\circ} \mathrm{C}$ for $15 \mathrm{~s}$ and $60^{\circ} \mathrm{C}$ for $30 \mathrm{~s}$. A final denaturation step was included to verify the amplification of a single PCR product for each reaction. PCR product size was verified by agarose gel electrophoresis of amplified products (data not shown). Threshold cycle values were obtained from the ABI 7900 Sequence Detection software (Applied Biosystems). Linearity over the 20- to 40-cycle range was established by standard dilution curves. All reactions were done in triplicate and the values averaged. A starting total RNA concentration of 5 ng was used for each sample. The $N$. benthamiana Actin gene was used as a control for normalization: Actin forward was 5'-CCCAGGTATTGCCGATAGAA-3' and Actin reverse was 5'-CATCTGTTGGAAGGTGCTGA-3'.

\section{Protein extraction and immunoblot analysis.}

Nicotiana leaf tissue was ground directly in Laemmli sample buffer (Bio-Rad, Hercules, CA, U.S.A.). Samples were spun at $16,000 \times g$ for $5 \mathrm{~min}$ and the supernatant removed to a new tube. Protein was quantified using the Bio-Rad Protein D kit per the manufacturer's instructions. Bulk protein $(15 \mu \mathrm{g})$ was heated to $95^{\circ} \mathrm{C}$ for $5 \mathrm{~min}$, then loaded onto a 4 to $20 \%$ Tris-HCl gel (Bio-Rad). Gels were transferred onto nylon membrane, then detected using anti-PsbO or -PsbQ primary and AP-conjugated goat-anti-rabbit secondary antibody with BCIP/ NBT substrate (KPL, Gaithersburg, MD, U.S.A.).

\section{SA extraction and quantification.}

SA was extracted and quantified as previously described, with the following modifications (Meuwly and Metraux 1993). Plant tissues were homogenized under liquid nitrogen and extracted with $3 \mathrm{ml}$ of $70 \%$ methanol, then spun at $20,000 \times g$ for 10 min. The supernatant was removed to a new tube, $3 \mathrm{ml}$ of $90 \%$ methanol was used to reextract the tissue pellet, and the supernatant was then spun at $20,000 \times g$ for $10 \mathrm{~min}$. The supernatant from the $90 \%$ methanol extraction was combined with the 
supernatant from the $70 \%$ methanol extraction and the mixture was spun for a third time at $20,000 \times g$ for 15 min to ensure the removal of any solid material. The methanol mixture was transferred to a new tube and evaporated under a stream of nitrogen. The extracted products were redissolved in $1 \mathrm{ml}$ of $50 \%$ methanol, and $250 \mathrm{ng}$ of 2-methoxybenzoic acid was added as internal standard to the combined supernatant for quantification. Centrifugation at $10,000 \times g$ was performed to remove insoluble materials. The supernatant was separated and the solvent removed under nitrogen. The dry material was resuspended in $1 \mathrm{ml}$ of $5 \%$ trichloroacetic acid, centrifuged at $10,000 \times g$ to remove insoluble material, and extracted three times with $0.5 \mathrm{ml}$ of a mixture of cyclohexene-ethyl acetate (50:50). The extracted materials in the organic solvent were dried under nitrogen and resuspended in $200 \mu \mathrm{l}$ of water/acetonitrile (90:10) containing $0.01 \%$ formic acid and filtered with a $0.22-\mu \mathrm{m}$ filter for high-performance liquid chromatography (HPLC) analysis.

The internal standard and the SA were analyzed with an Agilent 1100 HPLC instrument equipped with a C18, 5- $\mu$ m (4.6 by $50 \mathrm{~mm}$ ) Acclaim 120 column (Dionex, Sunnyvale, CA, U.S.A.), with a flow rate of $0.5 \mathrm{ml} / \mathrm{min}$ and the following water/acetonitrile (formic acid $0.01 \%$ ) gradient: starting with $10 \%$ acetonitrile that was linearly increased up to $25 \%$ of acetonitrile after $3 \mathrm{~min}$, followed by another increase to $40 \%$ acetonitrile at $7 \mathrm{~min}$. After elution of the SA at $7.8 \mathrm{~min}$ and internal standard (2-metoxybenzoic acid) at 8.9-min peaks, the column was rinsed with $90 \%$ acetonitrile for $5 \mathrm{~min}$ and reequilibrated under the initial condition for $15 \mathrm{~min}$. Analyte detection was achieved with a fluorescence detector (Agilent 1100) set at 306-nm excitation and 365-nm emission to monitor the elution of the 2-metoxybenzoic acid and programmed to change to $408 \mathrm{~nm}$ emission at $8.4 \mathrm{~min}$ for SA. In the original method, $\mathrm{KH}_{2} \mathrm{PO}_{4}$ was used to adjust the $\mathrm{pH} 2.6$ of the elution solvent but, in our procedure, $0.01 \%$ formic acid was added to the eluting solvents to achieve a sharper separation between the internal standard and the SA without affecting fluorescent emission. The reported SA concentration was determined using a calibration curve and the corresponding values and standard deviation are the average of duplicate extractions, with three injections of each.

\section{ACKNOWLEDGMENTS}

Several individuals provided technical support with the experiments described in this manuscript. E. Lutton, D. Hancock, W. Hershberger, S. Lyons, D. Morgens, and M. Whitaker (United States Department of Agriculture-Agricultural Research Service, AFRS, Kearneysville, WV, U.S.A.) assisted in many aspects of experimental setup and data collection.

\section{LITERATURE CITED}

Abbink, T. E., Peart, J. R., Mos, T. N., Baulcombe, D. C., Bol, J. F., and Linthorst, H. J. 2002. Silencing of a gene encoding a protein component of the oxygen-evolving complex of photosystem II enhances virus replication in plants. Virology 295:307-319.

Ahlquist, P. 2006. Parallels among positive-strand RNA viruses, reversetranscribing viruses and double-stranded RNA viruses. Nat. Rev. Microbiol. 4:371-382.

Alexander, D., Goodman, R. M., Gut-Rella, M., Glascock, C., Weymann, K., Friedrich, L., Maddox, D., Ahl-Goy, P., Luntz, T., and Ward E. 1993. Increased tolerance to two oomycete pathogens in transgenic tobacco expressing pathogenesis-related protein 1a. Proc. Natl. Acad. Sci. U.S.A. 90:7327-7331.

Antoniw, J. F., and White, R. F. 1980. The effects of aspirin and polyacrylic acid on soluble leaf proteins and resistance to virus infection in five cultivars of tobacco. Phytopathol. Z. 98:331-341.

Baker, C., and Orlandi, E. 1995. Active oxygen in plant pathogenesis. Annu. Rev. Phytopathol. 33:299-321.

Balachandran, S., and Osmond, C. B. 1994. Susceptibility of tobacco leaves to photoinhibition following infection with two strains of Tobacco mosaic virus under different light and nitrogen nutrition regimes. Plant Physiol. 104:1051-1057.

Barajas, D., Jiang, Y., and Nagy, P. D. 2009. A unique role for the host ESCRT proteins in replication of Tomato bushy stunt virus. PLoS Pathog. 5:e1000705. Published online.

Baulcombe, D. 2004. RNA silencing in plants. Nature 431:356-363.

Bawden, F., and Roberts, F. 1947. The influence of light intensity on the susceptibility of plants to certain viruses. Ann. Appl. Biol. 34:286-296.

Bawden, F., and Roberts, F. 1948. Photosynthesis and predisposition of plants to infection with certain viruses. Ann. Appl. Biol. 35:418-428.

Biehl, A., Richly, E., Noutsos, C., Salamini, F., and Leister, D. 2005. Analysis of 101 nuclear transcriptomes reveals 23 distinct regulons and their relationship to metabolism, chromosomal gene distribution and co-ordination of nuclear and plastid gene expression. Gene 3:344:3341.

Bowles, D. 1990. Defense-related proteins in higher plants. Annu. Rev. Biochem. 59:873-907.

Burch-Smith, T. M., Anderson, J. C., Martin, G. B., and Dinesh-Kumar, S. P. 2004. Applications and advantages of virus induced gene silencing (VIGS) for gene function studies in plants. Plant J. 39:734-746.

Cameron, R., Paiva N., Lamb C., and Dixon R. 1999. Accumulation of salicylic acid and $P R-1$ gene transcripts in relation to the systemic acquired resistance (SAR) response induced by Pseudomonas syringae pv. tomato in Arabidopsis. Physiol. Mol. Plant Pathol. 55:121-130.

Caplan, J., Mamilapalli, P., Burch-Smith T., Czymmek K., and DineshKumar, S. 2008. Chloroplastic protein NRIP1 mediates innate immune receptor recognition of a viral effector. Cell 132:449-462.

Cheo, P. 1971. Effect in different plant species of continuous light and dark treatment on Tobacco mosaic virus replicating capacity. Virology 46:256-265.

Conrath, U., Thulk, O., Katz, V., and Schwindling, S. 2001. Priming as a mechanism in induced systemic resistance of plants. Eur. J. Plant Pathol. 107:113-119.

Curto, M., Camafeita, E., López, J. A., Maldonado, A. M., Rubiales, D., and Jorrín, J. V. 2006. A proteomic approach to study pea (Pisum sativum) responses to powdery mildew (Erysiphe pisi). Proteomics 6:S163-S174.

Dangl, J., Dietrich, R., and Richberg, M. 1996. Death don't have no mercy: Cell Death programs in plant-microbe interactions. Plant Cell 8:1793-1807.

Dardick, C. 2007. Comparative expression profiling of Nicotiana benthamiana leaves systemically infected with three fruit tree viruses. Mol. Plant-Microbe Interact. 20:1004-1017.

Davis, H., Daniels, M., and Dow, J. 1997. Induction of extracellular matrix glycoproteins in Brassica petioles by wounding and in response to Xanthomonas campestris. Mol. Plant-Microbe Interact. 10:812-820.

Doke, N. 1983. Involvement of superoxide anion generation in the hypersensitive response of potato tuber tissue to infection with an incompatible race of Phytophthora infestans and to the hyphal wall components. Physiol. Plant Pathol. 23:345-357.

Ellis, R. J., and Hartley, M. R. 1974. Biochemistry of Nucleic Acids, Vol. 6. Medical and Technical Publishing Co. Ltd., Lancaster, U.K.

Elstner, E. 1991. Active Oxygen/oxidative Stress in Plant Metabolism. American Society of Plant Biologists Press, Rockville, MD, U.S.A.

Esau, K., and Cronshaw, J. 1967. Relation of tobacco mosaic virus to the host cells. J. Cell Biol. 33:665-678.

Gaffney, T., Friedrich, L., Vernooij, B., Negrotto, D., Nye, G., Uknes, S., Ward, E., Kessmann, H., and Ryals, J. 1993. Requirement of salicylic acid for the induction of systemic acquired resistance. Science 216:754756.

Garcion, C., Lohmann, A., Lamodière, E., Catinot, J., Buchala, A., Doermann, P., and Métraux, J. P. 2008. Characterization and biological function of the ISOCHORISMATE SYNTHASE2 gene of Arabidopsis. Plant Physiol. 147:1279-1287.

Genoud, T., Buchala, A. J., Chua, N. H., and Métraux, J. P. 2002. Phytochrome signaling modulates the SA-perceptive pathway in Arabidopsis. Plant J. 31:87-95.

Glazebrook, J. 2001. Genes controlling expression of defense responses in Arabidopsis-2001 status. Curr. Opin. Plant Biol. 4:301-308.

Gorovits, R., Akad, F., Beery, H., Vidavsky, F., Mahadav, A., and Czosnek, H. 2007. Expression of stress-response proteins upon whitefly-mediated inoculation of Tomato yellow leaf curl virus in susceptible and resistant tomato plants. Mol. Plant-Microbe Interact. 20:1376-1383.

Granett, A. L., and Shalla, T. A. 1970. Discrepancies in the intracellular behavior of three strains of Tobacco mosaic virus, two of which are serologically indistinguishable. Phytopathology 60:419-425.

Greenberg, J., Guo, A., Klessig, D., and Ausuble, F. 1994. Programmed cell death in plants: A pathogen-triggered response activated coordinately with multiple defense functions. Cell 77:551-563.

Griebel, T., and Zeier, J. 2008. Light regulation and daytime dependency of inducible plant defenses in Arabidopsis: Phytochrome signaling con- 
trols systemic acquired resistance rather than local defense. Plant Physiol. 147:790-801.

Gundlach, H., Müller, M., Kutchan, T., and Zenk, M. 1992. Jasmonic acid is a signal transducer in elicitor-induced plant cell cultures. Proc. Natl. Acad. Sci. U.S.A. 89:2389-2393.

Hatta, T., and Matthews, R. E. 1974. The sequence of early cytological changes in Chinese cabbage leaf cells following systemic infection with Turnip yellow mosaic virus. Virology 59:383-396.

Hatta, T., Bullivant, S., and Matthews, R. E. 1973. Fine structure of vesicles induced in chloroplasts of Chinese cabbage leaves by infection with Turnip yellow mosaic virus. J. Gen. Virol. 20:37-50.

Helms, K. 1965. Role of temperature and light in lesion development of Tobacco mosaic virus. Nature 205:421-422.

Helms, K., and McIntyre, G. A. 1967. Light induced susceptibility of Phaseolus vulgaris L. to Tobacco mosaic virus infection. Virology 31:191-196.

Hodgson, R. A., Beachy, R. N., and Pakrasi, H. B. 1989. Selective inhibition of photosystem II in spinach by Tobacco mosaic virus: An effect of the viral coat protein. FEBS (Fed. Eur. Biochem. Soc.) Lett. 245:267270.

Jelenska, J., Yao, N., Vinatzer, B., Wright, C., Brodsky, J., and Greenberg , J. 2007. A J domain virulence effector of Pseudomonas syringae remodels host chloroplasts and suppresses defenses. Curr Biol. 17:499-508.

Jimenez, I., Lopez, L., Alamillo, J., Valli, A., and Garcia, J. 2006. Identification of a Plum pox virus $\mathrm{CI}$-interacting protein from chloroplast that has a negative effect in virus infection. Mol. Plant-Microbe Interact. 19:350-358.

Jin, Y., Ma, D., Dong, J., Li, D., Deng, C., Jin, J., and Wang, T. 2007. The HC-Pro protein of Potato virus $Y$ interacts with NtMinD of tobacco. Mol. Plant-Microbe Interact. 20:1505-1511.

Jones, A., Bennett, M., Mansfield, J., and Grant, M. 2006. Analysis of the defense phosphoproteome of Arabidopsis thaliana using differential mass tagging. Proteomics 6:4155-4165.

Kauss, H., and Jeblick, W. 1995. Pretreatment of parsley suspension cultures with salicylic acid enhances spontaneous and elicited production of $\mathrm{H}_{2} \mathrm{O}_{2}$. Plant Physiol. 108:1171-1178.

Kauss, H., Theisinger-Hinkel, E., Mindermann, R., and Conrath, U. 1992. Dichloroisonicotinic and salicylic acid, inducers of systemic acquired resistance, enhance fungal elicitor responses in parsley cells. Plant J. 2:655-660.

Kauss, H., Franke, R., Krause, K., Conrath, U., Jeblick, W., Grimmig, B., and Matern, U. 1993. Conditioning of parsley (Petroselinum crispum) suspension cells increases elicitor induced incorporation of cell wall phenolics. Plant Physiol. 102:459-466.

Kim, B., Masuta, C., Matsuura, H., Takahashi, H., and Inukai, T. 2008. Veinal necrosis induced by Turnip mosaic virus infection in Arabidopsis is a form of defense response accompanying HR-like cell death. Mol. Plant-Microbe Interact. 21:260-268.

Kim, M., da Cunha, L., McFall, A., Belkhadir, Y., DebRoy, S., Dangl, J., and Mackey, D. 2005. Two Pseudomonas syringae type III effectors inhibit RIN4-regulated basal defense in Arabidopsis. Cell 121:749-759.

Klessig, D. F., and Malamy, J. 1994. The salicylic acid signal in plants. Plant Mol. Biol. 26:1439-1458.

Kohler, A., Schwindling, S., and Conrath, U. 2002. Benzothiadiazoleinduced priming for potentiated responses to pathogen infection, wounding, and infiltration of water into leaves requires the NPRI/NIMI gene in Arabidopsis. Plant Physiol. 128:1046-1056.

Kopek, B. G., Perkins, G., Miller, D. J., Ellisman, M. H., and Ahlquist, P. 2007. Three-dimensional analysis of a viral RNA replication complex reveals a virus-induced mini-organelle. PLos Biol. 5:e220. Published online.

Kumagai, M. H., Donson, J., Della-Cioppa, G., Harvey, D., Hanley, K., and Grill, L. K. 1995. Cytoplasmic inhibition of carotenoid biosynthesis with virus-derived RNA. Proc. Natl. Acad. Sci. U.S.A. 92:1679-1683.

Lebel, E., Heifetz, P., Thorne, L., Uknes, S., Ryals, J., and Ward, E. 1998. Functional analysis of regulatory sequences controlling PR-1 gene expression in Arabidopsis. Plant J. 16:223-233.

Lehto, K., Tikkanen, M., Hiriart, J. B., Paakkarinen, V., and Aro, E. M. 2003. Depletion of the photosystem II core complex in mature tobacco leaves infected by the flavum strain of Tobacco mosaic virus. Mol. Plant Microbe Interact. 16:1135-1144.

Lellis, A. D., Kasschau, K. D., Whitham, S. A., and Carrington, J. C. 2002 Loss-of susceptibility mutants of Arabidopsis thaliana reveal an essential role for eIF(iso)4E during potyvirus infection. Curr. Biol. 12:1046-1051.

Malamy, J., Carr, J. P., Klessig, D. F., and Raskin, I. 1990. Salicylic acid: A likely endogenous signal in the resistance response of tobacco to viral infection. Science 250:1002-1004.

Malamy, J., Hennig, J., and Klessig, D. F. 1992. Temperature dependent induction of salicylic acid and its conjugates during the resistance response to Tobacco mosaic virus infection. Plant Cell 4:359-366.
Martin, M. T., Cervera, M. T., Garcia, J. A., and Bonay, P. 1995. Properties of the active Plum pox potyvirus RNA polymerase complex in defined glycerol gradient fractions. Virus Res. 37:127-137.

Matthews, R. 1953a. Factors affecting the production of local lesions by plant viruses. I. The effect of time of day inoculation. Ann. Appl. Biol. 40:377-383.

Matthews, R. 1953b. Factors affecting the production of local lesions by plant viruses. II. Some effects of light, darkness and temperature. Ann. Appl. Biol. 40:556-565.

Maxwell, K., and Johnson, G. 2000. Chlorophyll fluorescence-A practical guide. J. Exp. Bot. 51:659-668.

McCartney, A. W., Greenwood, J. S., Fabian, M. R., White, K. A., and Mullen, R. T. 2005. Localization of the Tomato bushy stunt virus replication protein p33 reveals a peroxisome-to-endoplasmic reticulum sorting pathway. Plant Cell 17:3513-3531.

Meister, G., and Tuschl, T. 2004. Mechanisms of gene silencing by double-stranded RNA. Nature 431:343-349.

Métraux, J., Singer, H., Ryals, J., Ward, E., Wyss-Benz, M., Gaudin, J., Raschdorf, K., Schmid, E., Blum, W., and Inverardi, B. 1990. Increase in salicylic acid at the onset of systemic acquired resistance in cucumber. Science 250:1004-1006.

Meuwly, P., and Metraux, J.-P. 1993. Ortho-anisic acid as internal standard for the simultaneous quantification of salicylic acid and its putative biosynthetic precursors in cucumber leaves. Anal. Biochem. 214:500-505

Murphy, A. M., and Carr, J. P. 2002. Salicylic acid has cell-specific effects on Tobacco mosaic virus replication and cell-to-cell movement. Plant Physiol. 128:552-563.

Pineda, M., Sajani, C., and Barón, M. 2009. Changes induced by the Pepper mild mottle tobamovirus on the chloroplast proteome of Nicotiana benthamiana. Photosynth. Res. 103:31-45.

Prod'homme, D., Jakubiec, A., Tournier, V., Drugeon, G., and Jupin, I. 2003. Targeting of the Turnip yellow mosaic virus $66 \mathrm{~K}$ replication protein to the chloroplast envelope is mediated by the $140 \mathrm{~K}$ protein. J. Virol. 77:9124-9135.

Raskin, I. 1992. Role of salicylic acid in plants. Annu. Rev. Plant Physiol. Plant Mol. Biol. 43:439-463.

Reichel, C., and Beachy, R. N. 1998. Tobacco mosaic virus infection induces severe morphological changes of the endoplasmic reticulum. Proc. Natl. Acad. Sci. U.S.A. 95:11169-11174.

Reinero, A., and Beachy, R. 1986. Association of TMV coat protein with chloroplast membranes in virus-infected leaves. Plant Mol. Biol. 6:291301.

Reinero, A., and Beachy, R. 1989. Reduced photosystem II activity and accumulation of viral coat protein in chloroplasts of leaves infected with Tobacco mosaic virus. Plant Physiol. 89:111-116.

Restrepo-Hartwig, M. A., and Carrington, J. C. 1994. The Tobacco etch potyvirus 6-kilodalton protein is membrane associated and involved in viral replication. J. Virol. 68:2388-2397.

Ritzenthaler, C., Laporte, C., Gaire, F., Dunoyer, P., Schmitt, C., Duval, S., Piéquet, A., Loudes, A. M., Rohfritsch, O., Stussi-Garaud, C., and Pfeiffer, P. 2002. Grapevine fanleaf virus replication occurs on endoplasmic reticulum-derived membranes. J. Virol. 76:8808-8819.

Rodriguez-Cerezo, E., Findlay, K., Shaw, J. G., Lomonossoff, G. P., Qiu, S. G., Linstead, P., Shanks, M., and Risco, C. 1997. The coat and cylindrical inclusion proteins of a potyvirus are associated with connections between plant cells. Virology 236:296-306.

Ruiz, M. T., Voinnet, O., and Baulcombe, D. C. 1998. Initiation and maintenance of virus-induced gene silencing. Plant Cell 10:937-946.

Ryerson, D., and Heath, M. 1996. Cleavage of nuclear DNA into oligonucleosomal fragments during cell death induced by fungal infection or by abiotic treatments. Plant Cell 8:393-402.

Saitoh, H., and Terauchi, R. 2002. Virus-induced silencing of FtsH gene in Nicotiana benthamiana causes a striking bleached leaf phenotype. Genes Genet. Syst. 77:335-340.

Salonen, A., Ahola, T., and Kaariainen, L. 2005. Viral RNA replication in association with cellular membranes . Curr. Top. Microbiol. Immunol. 285:139-173

Schreiber, U., Schliwa, U., and Bilger, W. 1986. Continuous recording of photochemical and nonphotochemical chlorophyll fluorescence quenching with a new type of modulation fluorometer. Photosynth. Res. 10:5162.

Seo, S., Okamoto, M., Iwai, T., Iwano, M., Fukui, K., Isogai, A., Nakajima, N., and Ohashi, Y. 2000. Reduced levels of chloroplast FtsH protein in Tobacco mosaic virus-infected tobacco leaves accelerate the hypersensitive response. Plant Cell 12:917-932.

Shalla, T. A., Petersen, L. J., and Giunchedi, L. 1975. Partial characterization of virus-like particles in chloroplasts of plants infected with the U5 strain of TMV. Virology 66:94-105.

Shi, Y., Chen, J., Hong, X., Chen, J., and Adams, M. 2007. A Potyvirus P1 
protein interacts with the Rieske Fe/S protein of its host. Mol. Plant. Pathol. 8:785-790.

Shimizu, T., Satoh, K., Kikuchi, S., and Omura, T. 2007. The repression of cell wall- and plastid-related genes and the induction of defense-related genes in rice plants infected with Rice dwarf virus. Mol. Plant-Microbe Interact. 20:247-54

Slusarenko, A., Croft, K., and Volsey, C. 1991. Biochemistry and Molecular Biology of Plant-Pathogen Interactions. Oxford University Press, Oxford.

Sticher, L., Mauch-Mani, B., and Métraux, J. 1997. Systemic acquired resistance. Annu. Rev. Phytopathol. 35:235-270.

Strawn, M. A., Marr, S. K., Inuoe, K., Inada, N., Zubieta, C., and Wildermuth, M. C. 2007. Arabidopsis Isochorismate synthase functional in pathogeninduced salicylate biosynthesis exhibits properties consistent with a role in diverse stress responses. J. Biol. Chem. 282:5919-5933.

Thomma, B., Penninckx, I., Broekaert, W., and Cammue, B. 2001. The complexity of disease signaling in Arabidopsis. Curr. Opin. Immunol. 13:63-68.

Torrance, L., Cowan, G. H., Gillespie, T., Ziegler, A., and Lacomme, C. 2006. Barley stripe mosaic virus encoded proteins triple-gene block 2 and gamma B localize to chloroplasts in virus-infected monocot and dicot plants, revealing hitherto-unknown roles in virus replication. J. Gen. Virol. 87:2403-2411.

Torres, M., Jones, J., and Dangl, J. 2006. Reactive oxygen species signaling in response to pathogens. Plant Physiol. 141:373-378.

Turner, K. A., Sit, T. L., Callaway, A. S., Allen, N. S., and Lommel, S. A. 2003. Red clover necrotic mosaic virus replication proteins accumulate at the endoplasmic reticulum. Virology 320:276-290.

Uknes, S., Winter, A. M., Delaney, T., Vernooij, B., Morse, A., Friedrich, L., Nye, G., Potter, S., Ward, E., and Ryals, J. 1993. Biological induction of systemic acquired resistance in Arabidopsis. Mol. Plant-Microbe Interact. 6:692-698.

van Loon, L., Rep, M., and Pieterse, C. 2006. Significance of inducible defense-related proteins in infected plants. Annu. Rev. Phytopathol. 44:135-162.
Vlot, A., Klessig, D, and Park, S. 2008. Systemic acquired resistance: The elusive signal(s). Curr. Opin. Plant Biol. 11:436-442.

Ward, E., Uknes, S., Williams, S., Dincher, S., Wiederhold, D., Alexander, D., Ahl-Goy, P., Métraux, J., and Ryals, J. 1991. Coordinate gene activity in response to agents that induce systemic acquired resistance. Plant Cell 3:1085-1094.

Wei, T., Huang, T. S., McNeil, J., Laliberté, J. F., Hong, J., Nelson, R., and Wang, A. 2009. Sequential recruitment of the endoplasmic reticulum and chloroplasts for plant potyvirus replication. J. Virol. 84:799-809.

White, R. F. 1979. Acetylsalicylic acid (aspirin) induces resistance to tobacco mosaic virus in tobacco. Virology 99:410-412.

Wildermuth, M., Dewdney, J., Wu, G., and Ausubel, F. M. 2001. Isochorismate synthase is required to synthesize salicylic acid for plant defense. Nature 414:562-565.

Wiltshire, G. 1956. The effect of darkening on the susceptibility of plants to infection with viruses. I. Relation to changes in some organic acids in the French bean. Ann. Appl. Biol. 44:233-248.

Xiang, Y., Kakani, K., Reade, R., Hui, E., and Rochon, D. 2006. A 38 amino-acid sequence encompassing the arm domain of the Cucumber necrosis virus coat protein functions as a chloroplast transit peptide in infected plants. J. Virol. 80:7952-7964.

Yarwood, C. E. 1956. Further aids in virus inoculations. (Abstr.) Phytopathology 46:32.

Yang, C., Guo, R., Jie, F., Nettleton, D., Peng, J., Carr, T., Yeakley, J., Fan, J., and Whitham, S. 2007. Spatial analysis of Arabidopsis thaliana gene expression in response to Turnip mosaic virus infection. Mol. PlantMicrobe Interact. 20:358-70.

Zeier, J., Pink, B., Muller, M., and Berger, S. 2004. Light conditions influence specific defense responses in incompatible plant-pathogen interactions: Uncoupling systemic resistance from salicylic acid and $\operatorname{Prl}$ accumulation. Planta 219:673-683.

Zhou, W., Eudes, F., and Laroche, A. 2006. Identification of differentially regulated proteins in response to a compatible interaction between the pathogen Fusarium graminearum and its host, Triticum aestivum. Proteomics 6:4599-4609. 